\title{
Arsenic and Antimony in Hydrothermal Plumes from the Eastern Manus Basin, Papua New Guinea
}

\author{
Zhigang Zeng $\mathbb{D}^{1,2,3}$ Xiaoyuan Wang $\mathbb{D}^{1,2}$ Haiyan Qi, ${ }^{1}$ and Bowen Zhu ${ }^{1,3}$ \\ ${ }^{1}$ Seafloor Hydrothermal Activity Laboratory, CAS Key Laboratory of Marine Geology and Environment, Institute of Oceanology, \\ Chinese Academy of Sciences, Qingdao 266071, China \\ ${ }^{2}$ Laboratory for Marine Mineral Resources, Qingdao National Laboratory for Marine Science and Technology, Qingdao 266071, China \\ ${ }^{3}$ University of Chinese Academy of Sciences, Beijing 100049, China
}

Correspondence should be addressed to Zhigang Zeng; zgzeng@ms.qdio.ac.cn and Xiaoyuan Wang; xyzhang@ms.qdio.ac.cn

Received 27 December 2017; Accepted 18 February 2018; Published 15 April 2018

Academic Editor: Franco Tassi

Copyright (C) 2018 Zhigang Zeng et al. This is an open access article distributed under the Creative Commons Attribution License, which permits unrestricted use, distribution, and reproduction in any medium, provided the original work is properly cited.

Studies on the concentrations of arsenic (As) and antimony (Sb) in seawater columns are very important for tracing hydrothermal plumes and understanding fluid characteristics of seafloor hydrothermal systems. The total As, $\mathrm{Sb}, \mathrm{Mn}$, and $\mathrm{Cl}^{-}$concentrations of three hydrothermal plume seawater column samples have been studied at Stations 18G, 18K, and 18B in the eastern Manus backarc basin, Bismarck Sea, Papua New Guinea. At Stations 18G and 18K, the plumes above North Su and near the Suzette site in the SuSu Knolls hydrothermal field are both enriched in As, Sb, and Mn and depleted in $\mathrm{Cl}$, as a result of contribution of As-SbMn-enriched and Cl-depleted vent fluid outputs to the hydrothermal plume, which is most likely generated in the subseafloor by fluid-rock interaction, magma degassing, or phase separation (boiling of hydrothermal fluid). The plume at Station 18B is enriched in $\mathrm{As}, \mathrm{Sb}, \mathrm{Mn}$, and $\mathrm{Cl}$, suggesting that $\mathrm{As}-\mathrm{Sb}-\mathrm{Mn}$-Cl-enriched fluid discharges from vents, which have been generated by fluid-rock interaction. The concentrations of $\mathrm{As}$ and $\mathrm{Sb}$ anomalous layers, like manganese $(\mathrm{Mn})$, are higher than those of the other layers in the three hydrothermal plume seawater columns. As and Sb with Mn showed a positive correlation $\left(R^{2}>0.8, p<0.05\right)$, and the distributions of As and Sb within the hydrothermal plume are not controlled by particle adsorption or biogeochemical cycles, suggesting that As and Sb, like Mn, can be used to detect and describe the characteristics of hydrothermal plumes in seawater environment. In addition, anomalous layer with As/Sb ratio lower than those of ambient seawater at the same temperature is found in the eastern Manus basin, suggesting that the As/Sb ratio may also act as an effective tracer reflecting the effect of hydrothermal activity on As and $\mathrm{Sb}$ in the seawater column.

\section{Introduction}

Hydrothermal plumes are potent tools for locating, characterizing, and quantifying seafloor hydrothermal discharge. A hydrothermal plume rises into the overlying seawater column until reaching a neutrally buoyant layer, at which point the buoyant driving force vanishes and the neutrally buoyant plume spreads laterally extending for many kilometers [1]. The physical and chemical characteristics of plumes are different from ambient seawater, thereby offering us an effective way for tracing their sources and distribution. Identifying hydrothermal plumes has mainly relied on a combination of temperature anomaly (e.g., [2-7]), turbidity or light transmission (e.g., [3, 5, 8-11]), and chemical anomalies of species such as iron $(\mathrm{Fe})$, manganese $(\mathrm{Mn})$, helium $(\mathrm{He})$, and methane $\left(\mathrm{CH}_{4}\right)$ (e.g., $\left.[6,12-19]\right)$.

Since 1990, studies on hydrothermal plumes in the eastern Manus back-arc basin have been carried out. For example, during the 21st cruise of Research Vessel (R/V) Akademik Mstislay Keldysh in April-June 1990, all seawater columns studied in the Manus basin showed turbidity anomalies (up to 1880 nephels, at $1600 \mathrm{~m}$ below sea level (BSL)), as well as anomalies in dissolved $\mathrm{Mn}$ (up to $44.8 \mathrm{nM}$, at $1975 \mathrm{~m}$ BSL) and in biogeochemical parameters $\left(\mathrm{CO}_{2}\right.$-assimilation up to $0.07 \mathrm{mM} \cdot$ day $^{-1}$, at $1950 \mathrm{~m} \mathrm{BSL} ; \mathrm{CH}_{4}$-oxidation up to $3.30 \mathrm{nM} \cdot \mathrm{day}^{-1}$, at $2150 \mathrm{~m} \mathrm{BSL}$ ) [14]. Later, in NovemberDecember 1990, large scale triple-layered buoyant plumes were revealed from seawater column anomalies of $\mathrm{CH}_{4}$ (up 
to $5.98 \mathrm{nM}$, at $1091 \mathrm{~m} \mathrm{BSL}$ ), Mn (up to $100 \mathrm{nM}$, at $1732 \mathrm{~m}$ BSL), $\mathrm{Al}$ (up to $1501 \mathrm{nM}$, at $1683 \mathrm{~m} \mathrm{BSL}$ ), and $\mathrm{pH}$ (up to 7.55 , at $1700 \mathrm{~m} \mathrm{BSL}$ ) in the eastern Manus basin during KH-90-3 (AQUARIUS) expedition [12]. In 1993, the first indications of hydrothermal activity $\sim 5 \mathrm{~km} \mathrm{NW}$ of North $\mathrm{Su}$ (near Station 18G) were obtained, which showed a $0.7 \%$ transmissometer anomaly (\% reduction in light transmission relative to background) at around $1450 \mathrm{~m}$ depth [11]. During the 1996 PACMANUS III expedition, the SuSu Knolls hydrothermal field was discovered by means of multiple realtime CTD (conductivity, temperature, depth) and transmissometry plume detection, leading to the mapping of two plume levels [22], and the depth range (1260-1460 m BSL) of the 1996 lower plume emanating [21] is different from that (1300-1600 $\mathrm{m}$ BSL) reported by McDonald et al. [11]. Further, during the 1997 PACMANUS IV cruise, the lower plume had disappeared and the upper plume had become more sharply cut off to the north and west, and samples from the plume peak showed transmissometer anomalies of up to $40 \%$ and temperatures of $0.05^{\circ} \mathrm{C}$ above the ambient levels at 1050-1150 m BSL [11].

Arsenic (As) - though often present in significant amounts in hydrothermal phases (e.g., $\mathrm{As}_{4} \mathrm{O}_{6}, \mathrm{AsO}, \mathrm{AsS}$, $\mathrm{AsCl}_{3}$, and $\mathrm{As}(\mathrm{OH})_{3}$ ) throughout the fluid evolution (e.g., [23-25]) - has been rarely investigated in seafloor hydrothermal system [26]. At higher temperatures $\left(>400^{\circ} \mathrm{C}\right)$, arsenic enrichment factors in the gas phase with respect to the magma phase are 100 to 1000 , suggesting an important transfer of As into the hydrosphere during magma degassing [27]. Moreover, antimony (Sb) is easily mobilized by high-temperature hydrothermal fluids [28].

In back-arc basin, $\mathrm{As}$ and $\mathrm{Sb}$ contents in vent fluids (Vai Lili fluid in the Lau Basin and PACMANUS fluid in the Manus basin; [29]) associated with seawater-acidic rock interaction and/or magma degassing were high, about 10- to 100 -fold higher than the values measured in midocean ridge fluids (fluid from the East Pacific Rise near $13^{\circ} \mathrm{N}$ and Lucky Strike fluid from the Mid-Atlantic Ridge; [29]), suggesting that these As and Sb contents are mostly controlled by the phase separation process of hydrothermal fluid, which is believed to be the primary mechanism causing large variations in the chlorinity of deep-sea hydrothermal fluids $[30,31]$, while some studies have shown that the concentration of $\mathrm{Sb}$ in the ocean is very low, with concentration of the order $1.64 \mathrm{nM}$ [32], suggesting that $\mathrm{Sb}$ anomalies of the seawater column can be used to identify hydrothermal plumes.

However, there are no reports on the distribution of As and $\mathrm{Sb}$ anomalies in hydrothermal plume water column from the eastern Manus back-arc basin. In this study, As, Sb, Mn, and chloride $\left(\mathrm{Cl}^{-}\right)$concentrations have been measured, in the hydrothermal plume water column samples from the eastern Manus basin. We describe the concentration patterns of As, $\mathrm{Sb}, \mathrm{Mn}$, and $\mathrm{Cl}$ in hydrothermal plumes, characterize the correlations between $\mathrm{As}, \mathrm{Sb}, \mathrm{Mn}$, and $\mathrm{Cl}$, attempt to reveal the influencing factors on these elements, and attempt to understand the origin of hydrothermal plume in the eastern Manus basin.

\section{Geological Setting}

In the eastern Manus back-arc basin, extension is occurring within a remnant Eocene-Oligocene island-arc crust [33], spreading at $<2 \mathrm{~cm} /$ year [34]. A series of en echelon volcanic ridges, 20 to $30 \mathrm{~km}$ long, $<5 \mathrm{~km}$ wide, and 500-700 $\mathrm{m}$ high, occupies the zone of extension between the Djaul and Weitin transform faults [34]. Moreover, this area has a variable basement composition, and lavas erupted along the ridges include the complete series from basalt to rhyolite [35-37].

There are four main hydrothermal fields: the PACMANUS field, DESMOS caldera $(23 \mathrm{~km}$ east of PACMANUS), SuSu Knolls field (40 km east of PACMANUS), and Solwara $12\left(3.7087^{\circ} \mathrm{S}, 151.8833^{\circ} \mathrm{E}\right.$, near Station $\left.18 \mathrm{~B}\right)$ [22, 35, 38-40] (Figure 1).

The PACMANUS field located on the Paul ridge is notable for its distinctly siliceous volcanic host rock (dacite and rhyodacite) [41-43] (Figure 1), and there are various sulfides and Fe-Si-Mn oxyhydroxides in this field (e.g., [35, 44]). Four high-temperature sites called Rogers Ruins, Roman Ruins, Satanic Mills, and Tsukushi and a low-temperature $\left(6^{\circ} \mathrm{C}\right)$ site called Snowcap were identified in this field $[42,45]$. Ocean Drilling Program (ODP) Leg 193 investigated the PACMANUS field, finding that the highest vent temperature measurement at gray smokers was $280^{\circ} \mathrm{C}$ [41] and that the salinities of the fluids are variable which indicates that phase separation (boiling of hydrothermal fluid) is occurring below the surface [33]. Moreover, the geochemical characteristics of PACMANUS fluids, such as negative $\delta \mathrm{D}_{\mathrm{H} 2 \mathrm{O}}$ values and $\delta^{34} \mathrm{~S}_{\mathrm{H} 2 \mathrm{~S}}$ values, low $\mathrm{pH}$ (at $25^{\circ} \mathrm{C}$ ) values, high fluorine $(\mathrm{F})$ concentration, and high $\mathrm{CO}_{2}$ content, reflect the magmatic fluid input hydrothermal fluids [46]. In addition, the ${ }^{87} \mathrm{Sr} /{ }^{86} \mathrm{Sr}$ and $\delta^{34} \mathrm{~S}$ signatures of anhydrite recovered at Roman Ruins and Snowcap are very different, suggesting the PACMANUS system experiences a complex interplay between hydrothermal fluid, magmatic fluid, and seawater.

$\mathrm{SuSu}$ Knolls field is in the most eastern part of the eastern Manus basin (Figure 1), extending for approximately $4 \mathrm{~km}$ in a north-northwest to south-southeast direction [21, 47], and is characterized by porphyritic dacitic volcanics forming three prominent, moderately sedimented, steep sided conical peaks informally known as North $\mathrm{Su}$, South $\mathrm{Su}$, and Suzette [48]. At North Su, fluid boiling at the seafloor is evident, and the majority of fluids exhibit salinities lower or higher than seawater, consistent with phase separation of hydrothermal fluids below the seafloor [37].

DESMOS caldera, hosted by basaltic andesite [49] and located on the southeast ridge in the eastern Manus basin (Figure 1), emitted white-smoker fluids rich in sulfate with temperatures of $88^{\circ} \mathrm{C}$ and $120^{\circ} \mathrm{C}$ [38]. Like the North Su fluid, abundant $\mathrm{CO}_{2}$ and excess $\mathrm{F}$ in the DESMOS fluid indicate magma degassing [37], and the basaltic andesite from the DESMOS caldera is altered by the interaction with hot acidic hydrothermal fluid (up to $340^{\circ} \mathrm{C}$ ) originating from the mixing of magmatic fluid and seawater [50].

Solwara 12 is located $25 \mathrm{~km}$ WNW of Solwara 1 (Suzette), on the SE edge of the DESMOS caldera on a distinctive knoll at around $1850 \mathrm{~m}$ to $1900 \mathrm{~m}$ BSL (Figure 1), and was discovered by Nautilus during the Fugro Solstice Target Generation 


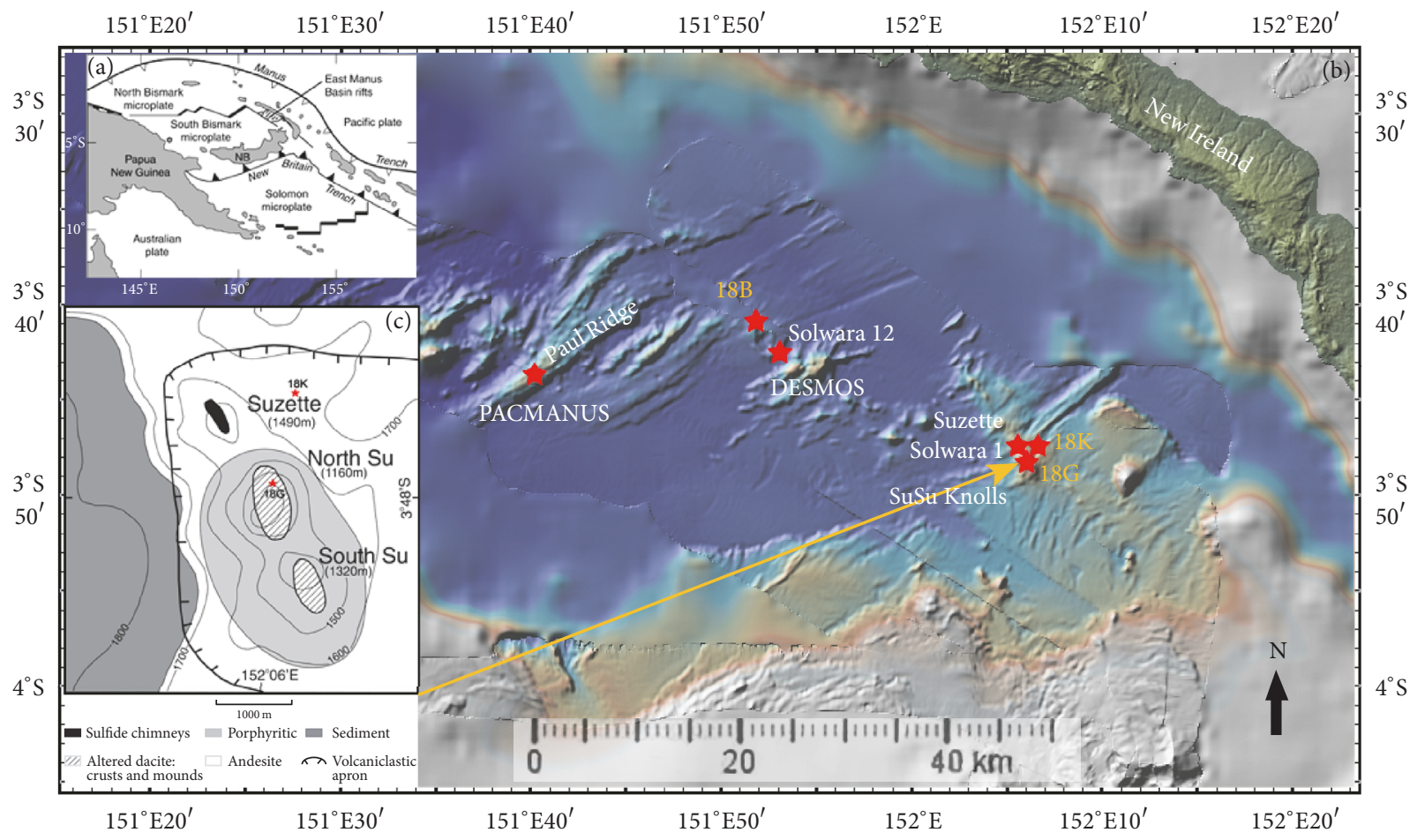

FIGURE 1: Distribution of CTD hydrocast stations. (a) Geological map showing the tectonic setting (from [20]). (b) The bathymetric chart of the survey area in the eastern Manus basin (bathymetric map and data from http://www.geomapapp.org/index.htm). (c) Map of the SuSu Knolls hydrothermal field showing the active Suzette, North Su, and South Su vent site (redrawn and modified from [21]). Station 18B is located about $1.8 \mathrm{~km}$ north-northwest of the DESMOS caldera rim; Station $18 \mathrm{~K}$ is $1.3 \mathrm{~km}$ to the east of Solwara 1, which is the name now used for the chimney field on the Suzette volcanic edifice, where the host rock is andesite; Station 18G lies between the crests of North Su and South Su where porphyritic dacite and altered dacite overlie older andesitic lavas. NB: New Britain.

and Target Testing program in 2009 [40]. Moreover, there is extensive sediment cover in the Solwara 12, the mapped chimney field is around $200 \mathrm{~m}$ across and includes clusters of old sulfide deposit, and outcropping chimneys are large up to $10 \mathrm{~m}$ high [40]. In addition, it is known that the hydrothermal vent fluids at the seafloor in the eastern Manus basin have high As (up to $18500 \mathrm{nM}$ ) and $\mathrm{Sb}$ (up to $188 \mathrm{nM}$ ) concentrations [29].

\section{Sampling and Analytical Methods}

3.1. Sample Collection. During the KX08-973 cruise of R/V KEXUE YIHAO in 2008, seawater column samples and temperature, salinity, and density data were collected at 3 hydrocast stations $\left(18 \mathrm{~B} 3.6827^{\circ} \mathrm{S}, 151.8636^{\circ} \mathrm{E}\right.$; $18 \mathrm{G} 3.7991^{\circ} \mathrm{S}$, $152.1005^{\circ} \mathrm{E}$; and $18 \mathrm{~K} 3.7884^{\circ} \mathrm{S}, 152.1066^{\circ} \mathrm{E}$ ) in the eastern Manus basin (Figure 1). At each station, seawater and hydrothermal plume samples were collected at different depths with a conductivity, temperature, and depth (CTD) aluminum rosette (Seabird) containing $2410 \mathrm{~L}$ Niskin bottles. These stations were operated as on-line measurements with a Seabird 911 CTD coupled to a Carousel water sampler SBE 32. A total of 33 hydrothermal plume water samples were taken from different depths with a CTD rosette of 11 "Niskin" bottles. To ensure the highest possible purity of the samples, the Niskin bottles were cleaned thoroughly using $1 \% \mathrm{v} / \mathrm{v}$ $\mathrm{HNO}_{3}$ solution and Milli-Q water before usage.
In general, hydrothermal plumes can rise tens to hundreds of meters to a level of neutral buoyancy. Therefore, seawater samples collected at water depths shallower than $1000 \mathrm{~m}$ were considered normal seawater. Upon recovery of the Niskin bottles, $30 \mathrm{~cm}$ long Teflon tubes were inserted through the outlet at the bottom of the Niskin bottles, and the first $200 \mathrm{ml}$ of the liquid was discarded. The remaining aqueous samples were collected in $5 \mathrm{~L}$ precleaned High Density Polyethylene bottles (the precleaning method is described in detail in Sampling and Sample-Handling Protocols for GEOTRACES Cruises).

The probes were obtained from the manufacturers and calibrated by the National Center of Ocean Standards and Metrology (NCOSM) in July 2007. The measurement accuracies were $\pm 0.001^{\circ} \mathrm{C}$ for temperature, $\pm 0.0003 \mathrm{~S} / \mathrm{m}$ for conductivity, and $\pm 0.015 \%$ of full-scale range for pressure, respectively.

Temperature anomaly $(\Delta T)$ of the plume relative to ambient seawater was calculated using the formula proposed by Baker and Lupton [2], which is suitable for the Pacific, and the potential density and potential temperature data required for the formula were also obtained using the CTD. Further, because the entrainment of seawater, which had been considered in the calculation of the potential temperature anomaly of the horizontally spreading fluid at the equilibrium height [51], and the calculation of the penetration height of the hydrothermal plume [52], was not considered in this 
study, the calculated temperature anomaly value is lower than the actual value, but the trend with depth is significant. It is noteworthy that hydrothermal fluid samples could not be obtained due to the lack of sampling equipment during this cruise. However, we believe that the fluid data in the literature are reliable, and the hydrothermal activity in our survey field is steady [53].

3.2. Analytical Methods. A $250 \mathrm{ml}$ aliquot of unfiltered seawater was transferred into a precleaned Naglen polypropylene bottle for measuring $\mathrm{pH}$. In the ship laboratory, the $\mathrm{pH}$ of each aqueous sample was determined with a portable $\mathrm{pH}$ meter (JENCO 6010, resolution 0.01, automatic temperature compensation) immediately after collection at room temperature (approximately $25^{\circ} \mathrm{C}$ ). The $\mathrm{pH}$ meter was calibrated with buffer solutions of $\mathrm{pH} 4.00$ (potassium hydrogen phthalate $0.05 \mathrm{~mol} \mathrm{~L}^{-1}$ ) and 6.86 (mixed phosphate $0.025 \mathrm{~mol} \mathrm{~L}^{-1}$ ). The aqueous samples were filtered through $47 \mathrm{~mm}$ Merck Millipore $0.10 \mu \mathrm{m}$ nitrocellulose membrane into $1 \mathrm{~L}$ Naglen polypropylene bottles (previously soaked in $1: 1 \mathrm{HNO}_{3}$ for $48 \mathrm{~h}$, washed to neutral $\mathrm{pH}$ with deionized water and ultrapure water) within the ship laboratory immediately after collection from the Niskin bottles. Filtered water samples were acidified to $\mathrm{pH} 1.8$ using $2 \mathrm{M}$ ultrapure $\mathrm{HNO}_{3}$ (J. T. Baker), capped tightly, and resealed with Parafilm Sealing membrane.

The determination of total As and $\mathrm{Sb}$ concentrations was conducted at Qingdao Institute of Marine Geology, China Geological Survey Bureau. Following the analysis method in the national standards GB 17378.4-2007 and GB/T 5750.62006 of China, As and Sb were reduced to arsenic hydride and antimony hydride in an acidic solution and then were delivered by argon into the atomic fluorescence spectrophotometer (AFS) to be analyzed. The relative standard deviation (RSD) for As and Sb was $\pm 3 \%$ and $\pm 5 \%$, respectively. Mn was determined by inductively coupled plasma mass spectrometer (ICP-MS) using Re as an internal standard at the Institute of Oceanology, Chinese Academy of Sciences, through the method of sodium hydroxide coprecipitation with an RSD of $\pm 3 \%$. When measuring $\mathrm{As}, \mathrm{Sb}$, and $\mathrm{Mn}$, each sample was measured three times and the average was calculated. Reference materials NASS- 5 and SLRS- 4 offered by the National Research Council Canada were run as external standards to evaluate the accuracy, and all $\mathrm{As}, \mathrm{Sb}$, and $\mathrm{Mn}$ values measured in the standard materials were within the error range of standard values (Table 1). The detection limits were $0.13 \mathrm{nM}$ for $\mathrm{As}, 0.08 \mathrm{nM}$ for $\mathrm{Sb}$, and $0.36 \mathrm{nM}$ for $\mathrm{Mn}$. Cl concentrations in seawater samples were measured by ion chromatography at the Institute of Oceanology, Chinese Academy of Sciences, the anion exchange resin column (DIONEX AS12 column) was used, $3.5 \mathrm{mM} \mathrm{Na} \mathrm{CO}_{3} / 1.0 \mathrm{mM} \mathrm{NaHCO}$ was used as eluent at a flow rate of $1.2 \mathrm{~mL} / \mathrm{min}$, and the precision was $\pm 1 \%$.

\section{Results}

At Station 18B (located $1.8 \mathrm{~km}$ north-northwest of the DESMOS caldera rim), temperature anomaly increases continuously from $\sim 1500 \mathrm{~m}$ BSL, the maximum occurs at $1650 \mathrm{~m}$ BSL and is $0.024^{\circ} \mathrm{C}$ above the ambient seawater level (Figure 2(a)). The profile of Mn concentration with water depth is similar to that of the temperature anomaly, and the maximum $(79.3 \mathrm{nM}$ ) occurs at $1641 \mathrm{~m} \mathrm{BSL}$ (Figure 2(a)). Further, at Station $18 \mathrm{~B}, \mathrm{As}, \mathrm{Sb}$, and $\mathrm{Cl}$ in the seawater profile are enriched relative to ambient seawater, and the maximum concentrations occur at $1641 \mathrm{~m} \mathrm{BSL}$, which is consistent with the $\mathrm{Mn}$ and temperature anomalies in the hydrothermal plume water column (Table 1, Figure 3).

In the SuSu Knolls hydrothermal field, at Station $18 \mathrm{G}$ (situated between the crests of North $\mathrm{Su}$ and South $\mathrm{Su}$ ), the vertical column shows two distinct layers of temperature anomaly: the maximum temperature anomaly of the shallow layer (1070-1250 m BSL) is $0.056^{\circ} \mathrm{C}$, occurring at $1126 \mathrm{~m} \mathrm{BSL}$, and that of the deep layer $(1400-1550 \mathrm{~m} \mathrm{BSL})$ is $0.021^{\circ} \mathrm{C}$, occurring at $1493 \mathrm{~m}$ BSL (Figure 2(b)). The shallower layer in the hydrothermal plume water column is thicker, and the depth of the peak of the deeper layer is identical to the transmissometer anomaly peak of the plume detected in 1993 $(\sim 1450 \mathrm{~m})$ [11]. We are dealing with the lower plume, not the upper plume, because the upper plume water was not sampled at Station 18G. The profile of Mn concentration parallels that of the lower temperature anomaly at Station 18G, where the $\mathrm{Mn}$ concentration increases continuously from $\sim 1300 \mathrm{~m}$ BSL to $1492 \mathrm{~m}$ BSL (Figure 2(b)), with the maximum occurring at $1492 \mathrm{~m} \mathrm{BSL}$ and reaching $36.3 \mathrm{nM}$ (Mn is about 4 times the ambient seawater value ( $9.3 \mathrm{nM})$, Table 1). Further, As and $\mathrm{Sb}$ in the lower anomaly layer (at $1492 \mathrm{~m} \mathrm{BSL}$ ) are also slightly enriched (As and Sb are enriched by $\sim 12 \%$ and $\sim 24 \%$, resp., relative to ambient seawater) and depleted in $\mathrm{Cl}$ relative to ambient seawater at Station 18G (Table 1, Figure 3).

At Station 18K (lying $1.3 \mathrm{~km}$ to the east of Solwara 1, which is the name now used for the chimney field on the Suzette volcanic edifice), the vertical column also reveals two distinct anomalous temperature: the upper layer is at a depth of 1050-1300 $\mathrm{m}$ in which the maximum temperature anomaly is $0.041^{\circ} \mathrm{C}$ above ambient seawater, and the lower layer is at a depth of $1400-1550 \mathrm{~m}\left(\Delta T_{\max }\right.$ is $0.042^{\circ} \mathrm{C}$, at $\left.1450 \mathrm{~m} \mathrm{BSL}\right)$. The two anomalous layers are both deeper than those of the particulate plume discovered during the 1996 PACMANUS III marine expedition (1060-1140 m, 1260-1460 m) [21]; however, the depth of the maximum temperature anomaly of the deeper layer is identical to that of the transmissometer anomaly of the plume in 1993 above North Su ( 1450 m) [11]. Furthermore, we are only concerned with the lower plume, because the upper plume was also not sampled at Station 18K. Here, the maximum concentration of Mn (110.8 nM) occurs at $1500 \mathrm{~m}$ BSL (Mn is about 10 times the ambient seawater value $(14.8 \mathrm{nM})$ ) and is also in the same layer as the maximum temperature anomaly (Figure 2(c)). Further, at Station 18K, the maximum anomalies of $\mathrm{As}$ and $\mathrm{Sb}$ also occur at $1500 \mathrm{~m}$ (Figure 3), where As and $\mathrm{Sb}$ are all significantly enriched (As and $\mathrm{Sb}$ are enriched by $\sim 32 \%$ and $\sim 46 \%$, resp., relative to ambient seawater) (Table 1, Figure 3).

In addition, the water depth at Stations $18 \mathrm{G}$ and $18 \mathrm{~K}$ is shallower than that at Station 18B (1400-1700 m), and the As and $\mathrm{Sb}$ concentrations in seawater were $\sim 19 \mathrm{nM}$ and $\sim 2 \mathrm{nM}$, respectively. The variation in As at Station $18 \mathrm{~K}$ is larger than that at Station 18G (Table 1, Figure 3(a)). At Station 18K, the maximum concentration of As $(26.9 \mathrm{nM})$ is at $1500 \mathrm{~m}$, but at Station 18G the concentration of As increases with depth 


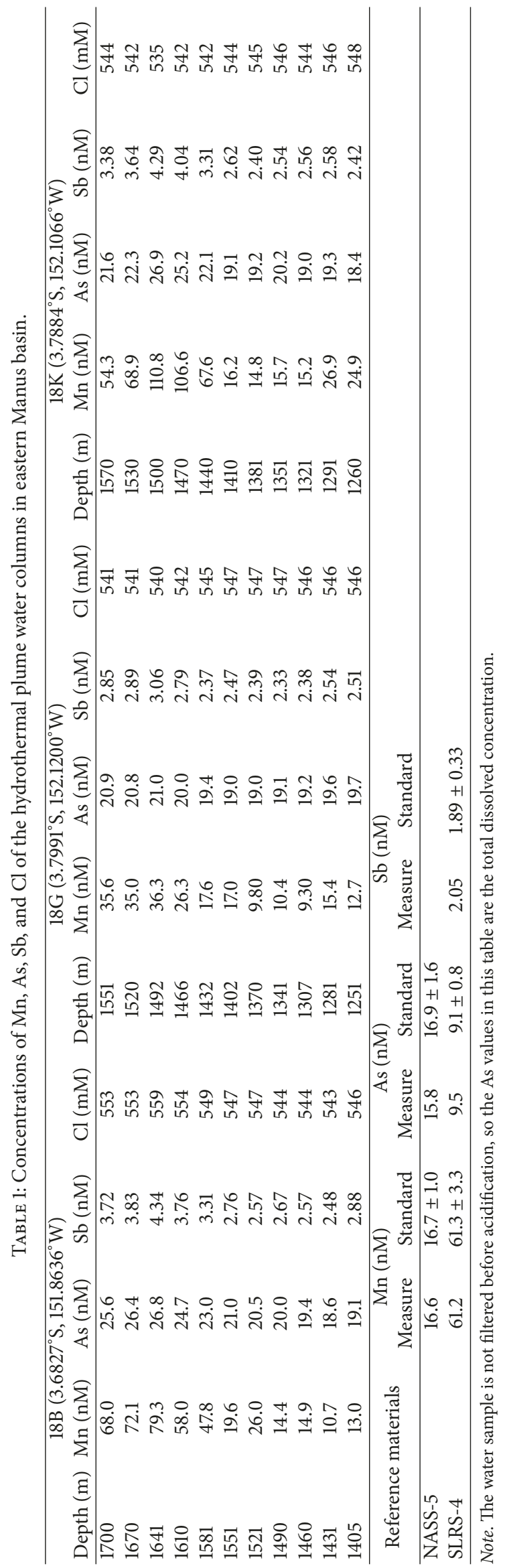




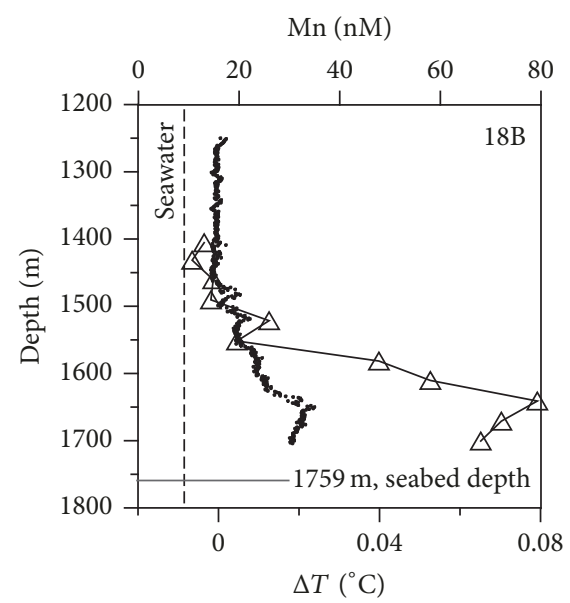

(a)

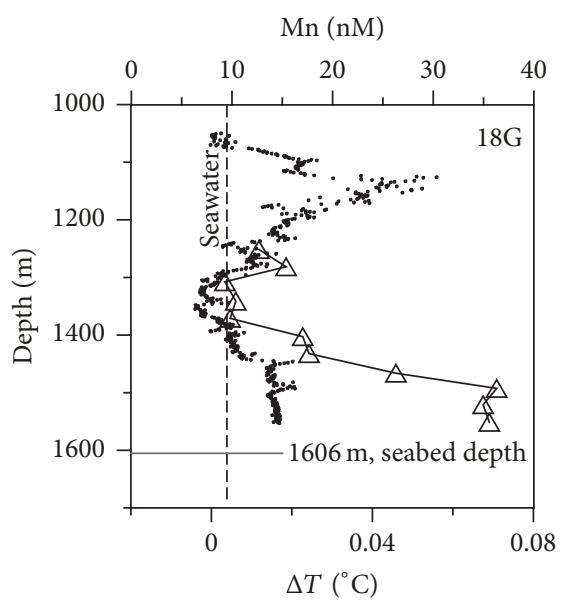

(b)

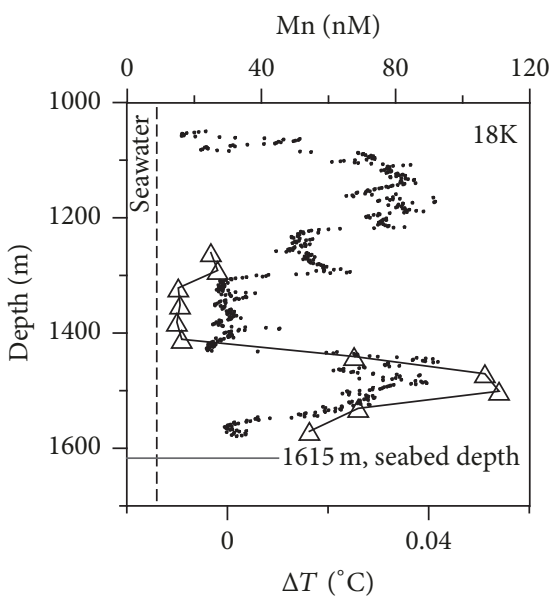

(c)

FIGURE 2: Vertical profiles of temperature and Mn at Stations $18 \mathrm{~B}$ (a), 18G (b), and $18 \mathrm{~K}$ (c). ".” denotes the temperature anomaly, and " $\Delta$ ” denotes the concentration of $\mathrm{Mn}$ in the water column samples. The dashed line represents the value of ambient seawater ( $\mathrm{Mn}$ data (9.30 $\mathrm{nM}$ ) are the minimum Mn content of the three water column samples) and that of temperature. The seabed depths at Stations 18B, 18G, and 18K are $1759 \mathrm{~m}, 1606 \mathrm{~m}$, and $1615 \mathrm{~m}$, respectively.

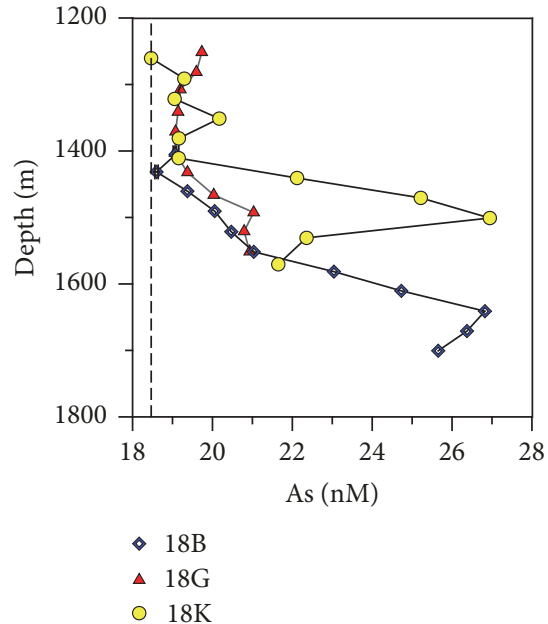

(a)

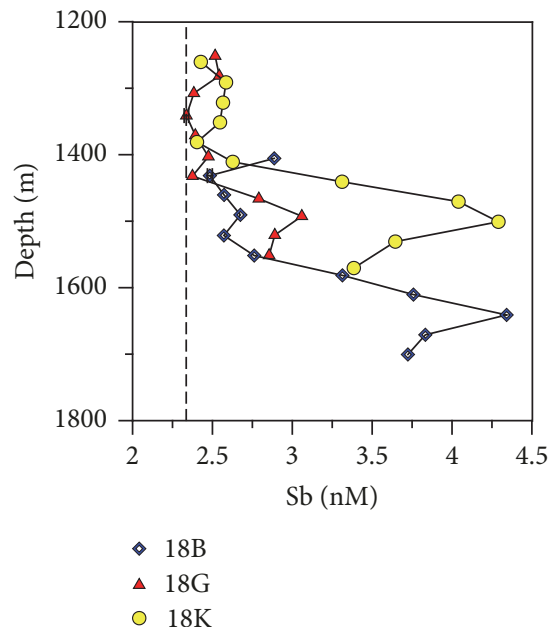

(b)

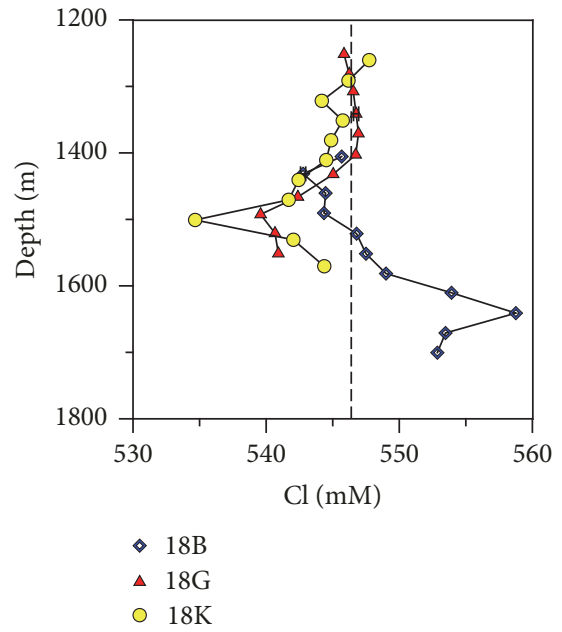

(c)

Figure 3: Vertical profiles of As (a), Sb (b), and Cl (c) at Stations 18B, 18G, and 18K. The dashed line represents the As (18.4 nM), Sb (2.33 nM), and $\mathrm{Cl}(546 \mathrm{mM})$ value of ambient seawater.

from $1400 \mathrm{~m}$ to $1600 \mathrm{~m}$. The variation of $\mathrm{Sb}$ concentration in the seawater profile at these two stations is similar, with both reaching a maximum at depths of $\sim 1500 \mathrm{~m}$ (Figure 3(b)).

\section{Discussion}

5.1. Anomalous Layers of Hydrothermal Plume Water Columns. At Station $18 \mathrm{~B}, \mathrm{As}, \mathrm{Sb}, \mathrm{Mn}$, and $\mathrm{Cl}$ in the water column are significantly enriched (at $1641 \mathrm{~m} \mathrm{BSL}, \mathrm{Mn}$ is about 8 times the ambient seawater value $(9.3 \mathrm{nM}, \mathrm{Mn}$ data from the minimum Mn content in the three water column samples), while As, $\mathrm{Sb}$, and $\mathrm{Cl}$ are enriched by $\sim 31 \%, \sim 47 \%$, and $\sim 4 \%$, respectively, relative to ambient seawater (As (18.4 nM), Sb $(2.33 \mathrm{nM})$, and $\mathrm{Cl}(546 \mathrm{mM})$ data from the respective As, $\mathrm{Sb}$, and $\mathrm{Cl}$ content in the three water column samples)), suggesting that the $\mathrm{As}, \mathrm{Sb}$, and $\mathrm{Cl}$ anomalies in the water column is consistent with the $\mathrm{Mn}$ and temperature anomalies (see Figures 2 and 3). This is mainly caused by the input of hydrothermal fluid produced by fluid-rock (mainly andesite and dacite) interaction which can generate high contents of As, $\mathrm{Sb}, \mathrm{Mn}$, and $\mathrm{Cl}[29,54]$. Furthermore, Station $18 \mathrm{~B}$ is located $1.8 \mathrm{~km}$ north-northwest of the DESMOS caldera rim, far away from the PACMANUS hydrothermal field and the Sb contents in the DESMOS fluid (Sb, <3.0 nM, [29]) are lower than those in the anomaly layer at Station $18 \mathrm{~B}$, suggesting that the chemical anomaly is not the result of hydrothermal plume drift from the DESMOS caldera (see Figure 1).

At Station $18 \mathrm{G}$ from the SuSu Knolls hydrothermal field, in the anomaly layer ( $60 \mathrm{~m}$ above the seafloor), $\mathrm{Cl}$ is slightly depleted relative to ambient seawater (lower than the 
background seawater by $546 \mathrm{mM}$ ), while $\mathrm{Mn}$, As, and Sb are slightly enriched ( $\mathrm{Mn}$ is about 3 times the background seawater value, As and Sb are enriched by $\sim 14 \%$ and $\sim 31 \%$, resp., relative to ambient seawater), reflecting the contribution of $\mathrm{Mn}$-As-Sb-enriched, Cl-depleted fluid to the hydrothermal plume.

Discharge of Cl-depleted fluid to the SuSu Knolls hydrothermal field has been reported during the investigation of the plume in 1997 [11]. The plume may be related to the vapors produced by magma degassing and/or phase separation and emanation of the condensed vapor phase. Abundant $\mathrm{CO}_{2}$ and excess fluorine in the North $\mathrm{Su}$ fluid are the indicators of magma degassing [37], and magma degassing $[27,38]$ may generate $\mathrm{Cl}$-depleted and As-enriched magmatic fluid relative to ambient seawater. At North $\mathrm{Su}$ in the $\mathrm{SuSu}$ Knolls hydrothermal field, phase separation, with emanations rich in $\mathrm{H}_{2} \mathrm{~S}$, very low in $\mathrm{Cl}$ in hydrothermal fluid, has taken place under the seafloor [37], generating Cl-depleted and slightly As-enriched (in the form of $\mathrm{As}(\mathrm{OH})_{3}$ ) vapors [27, 29]. The enrichment of $\mathrm{Sb}$ may also be related to the above two processes, since $\mathrm{Sb}, \mathrm{OH}^{-}$, and $\mathrm{Cl}^{-}$components will partition into the vapor phase during boiling and vapor-brine separation processes occurring in magmatic-hydrothermal systems [28]. Furthermore, the enrichment of $\mathrm{Sb}$ would be more strongly controlled by fluid-rock interaction [29]. The enrichment of $\mathrm{Mn}$ is controlled more strongly by seawaterrock interaction, because it cannot form volatile species in the same way as those of As and Sb, which are controlled by magma degassing and phase separation of hydrothermal fluid under acidic hydrothermal conditions, all suggesting that the Mn-As-Sb-enriched, Cl-depleted fluid was most likely generated in the subseafloor by mixing of different fluids that may be products of fluid-rock interaction, magma degassing, or phase separation (subcritical boiling). In addition, the lower plume at Station $18 \mathrm{G}$ may also be derived from South $\mathrm{Su}$, according to the particulate plume investigation during the 1996 PACMANUS III and 1997 PACMANUS IV expeditions [21].

At Station $18 \mathrm{~K}$, the maximum anomalies of $\mathrm{As}, \mathrm{Sb}, \mathrm{Mn}$, and $\mathrm{Cl}$ occur at about $70 \mathrm{~m}$ above the seafloor (Figures 2 and 3), where $\mathrm{Cl}$ is depleted relative to ambient seawater (lower than background seawater by $546 \mathrm{mM}$ ) while As, $\mathrm{Sb}$, and $\mathrm{Mn}$ are all enriched significantly (As and $\mathrm{Sb}$ are enriched by $\sim 46 \%$ and $\sim 84 \%$, resp., relative to background seawater; $\mathrm{Mn}$ is about 10 times the background seawater value). Like Station $18 \mathrm{G}$, the depletion of $\mathrm{Cl}$ is an indication of Cl-depleted fluid input, which may be related to magmatic fluid (like DESMOS fluid; [38]) and vapors produced by subsurface boiling and phase separation of hydrothermal fluid with a lower $\mathrm{Cl}$ concentration than in seawater (similar to the Lucky Strike and EPR $17-19^{\circ} \mathrm{S}$ fluids; [55]). The $\mathrm{Cl}$-depleted and gas-enriched fluids affected by subsurface boiling and phase separation of hydrothermal fluid exhibited relatively high As concentrations, consistent with the volatile character of $\mathrm{H}_{3} \mathrm{AsO}_{3}(\mathrm{aq})$ which is the dominating As species under these hydrothermal conditions [29], also indicating that the As-enriched and Cl-depleted fluid in the eastern Manus basin may be related to phase separation (enriched in vapor-derived low-chlorinity fluid) below the seafloor. The distinct enrichment of $\mathrm{Mn}$ is mainly due to seawater-rock interaction under the seafloor, and the enrichment of As and $\mathrm{Sb}$ may be linked to all of the above three processes: seawater-rock interaction, magma degassing, and boiling and phase separation of hydrothermal fluid (took place under subcritical conditions).

Moreover, there are two temperature anomalous layers in both casts at Stations $18 \mathrm{G}$ and $18 \mathrm{~K}$ (Figures 2(b) and $2(\mathrm{c})$ ), suggesting that the two distinct buoyant plumes are separated by seawater at ambient temperature (e.g., [40]). Compared to midocean ridge plumes, hydrothermal plumes in the eastern Manus basin are influenced by variable current directions and topography (e.g., [40]). Further, depending on the exact site within SuSu Knolls, the lower plume can include contributions from Solwara 1 (on Suzette), the crest of South Su (active black smokers), and small active sites (including Solwara 9) on the western flanks of North $\mathrm{Su}$ and South $\mathrm{Su}$, hence influencing depth range of the lower plume (see Figure 1; Lipton, 2008 [40]). It is possible that the hydrothermal plumes can change with time as well as distance from source and deep currents which can swing through 180 degrees at SuSu Knolls [40].

At Stations $18 \mathrm{G}$ and $18 \mathrm{~K}$, the lower plume is also enriched in both As and $\mathrm{Sb}$ relative to ambient seawater, and the maximum anomaly layers are also close to the $\mathrm{Mn}$ and temperature anomaly maxima, at $1492 \mathrm{~m}$ BSL and $1500 \mathrm{~m} \mathrm{BSL}$, respectively (Table 1; Figures 3(a) and 3(b)). These results are clearly suggestive of simple dilution as a plume advection or of profiles made in different parts (e.g., plume center and edge) of the same plume (e.g., [51]). The magnitude of the Sb anomaly at Station $18 \mathrm{~K}$ was less than that at Station $18 \mathrm{G}$, implying the $\mathrm{Sb}$ content possibly because the fluid at Station $18 \mathrm{G}$ leached considerable quantities of $\mathrm{Sb}$ from the upper dacite.

In the SuSu Knolls hydrothermal field, the vapors generated during magma degassing and boiling and phase separation of hydrothermal fluid are both rich in As and depleted in $\mathrm{Cl}^{-}$, and interactions between fluid and volcanic rock below the seafloor can produce high contents of $\mathrm{As}, \mathrm{Sb}$, and $\mathrm{Cl}^{-}$in the fluid; however, the extent of enrichment of $\mathrm{Cl}^{-}$ during this process is less than that of the depletion of $\mathrm{Cl}^{-}$ in magmatic fluid and vapors generated during boiling and phase separation of hydrothermal fluid, which results in the formation of As-enriched and Cl-depleted fluid, thus the Asenriched and $\mathrm{Cl}$-depleted fluid causing the anomaly in the seawater profile at Stations $18 \mathrm{G}$ and $18 \mathrm{~K}$ may be a product of the influx of magmatic gases $[37,38,56]$. Because $\mathrm{Sb}$ is not easily enriched in the vapor phase and whether or not it can be enriched in the magmatic fluid is not known, we cannot confirm that the observation of higher Sb in the hydrothermal fluid than in the seawater is due to the influence of magmatic fluid. In addition, the $\mathrm{Mn} / \Delta T$ ratios in the plume peak level at Stations $18 \mathrm{G}$ and $18 \mathrm{~K}$ are significantly different, $\sim 1820$ and $\sim 3640 \mathrm{nM} /{ }^{\circ} \mathrm{C}$, and $\mathrm{Mn}$ is more significantly enriched in the lower $18 \mathrm{~K}$ plume than in the $18 \mathrm{G}$ plume (Figures 2 (b) and $2(\mathrm{c})$ ), which suggest $18 \mathrm{~K}$ is closer than $18 \mathrm{G}$ to the hydrothermal vent fluid source of the lower plume.

5.2. Correlations between $\mathrm{As}, \mathrm{Sb}, \mathrm{Mn}$, and $\mathrm{Cl}$ in the Hydrothermal Plume. The correlations between As, Sb, and $\mathrm{Mn}$ in the 


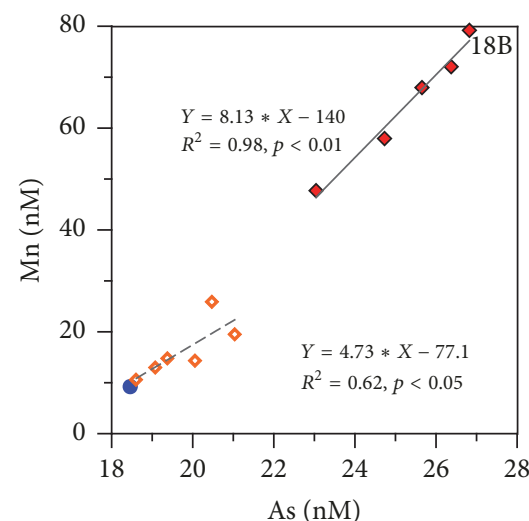

$\diamond$ Samples within the plume peak

$\diamond$ Background-dominated samples

- Ambient seawater

(a)

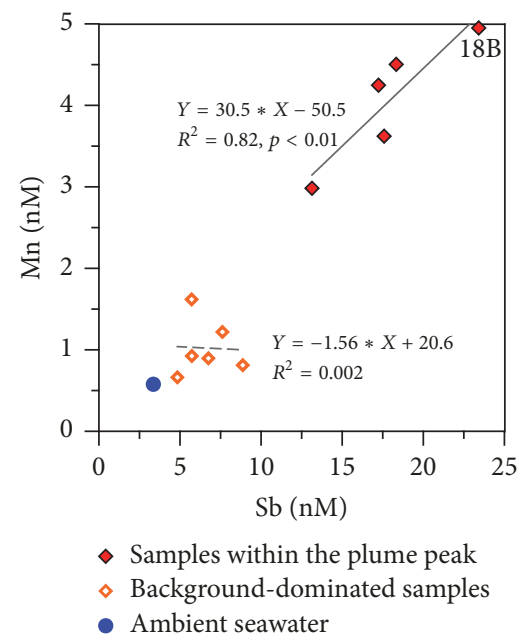

(d)

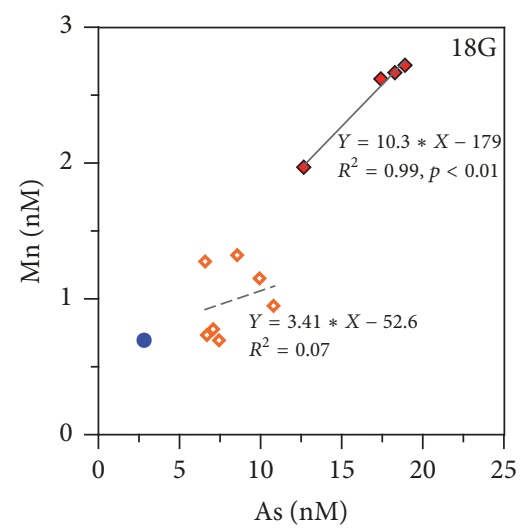

$\checkmark$ Samples within the plume peak

$\diamond$ Background-dominated samples

- Ambient seawater

(b)

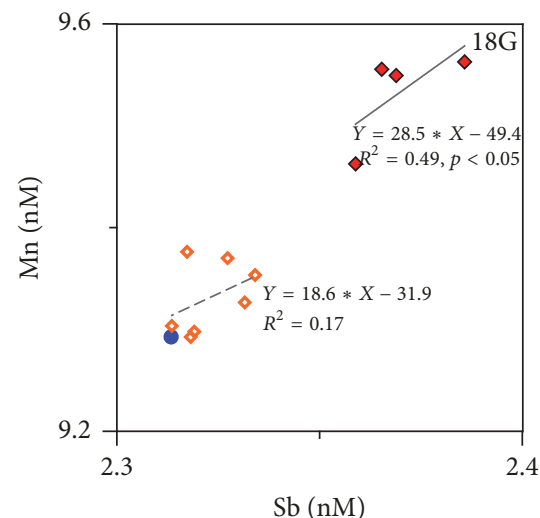

- Samples within the plume peak

$\diamond$ Background-dominated samples

- Ambient seawater

(e)

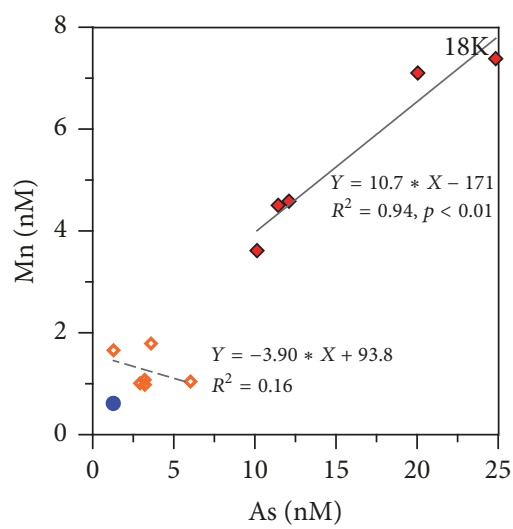

$\diamond$ Samples within the plume peak

$\checkmark$ Background-dominated samples

- Ambient seawater

(c)

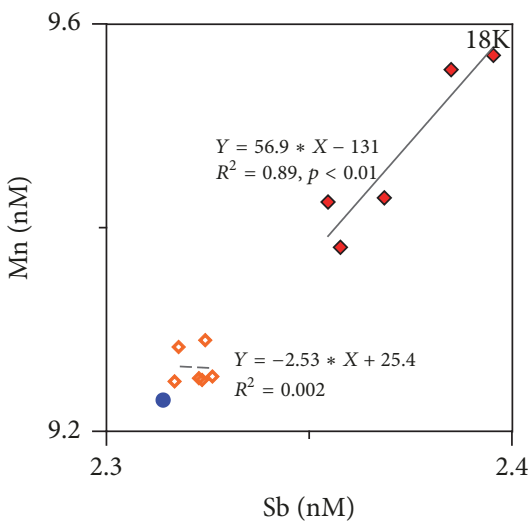

$\checkmark$ Samples within the plume peak

$\diamond$ Background-dominated samples

- Ambient seawater

(f)

Figure 4: Correlations between Mn and As at (a) Station 18B, (b) Station 18G, and (c) Station 18K; correlations between Mn and Sb at (d) Station 18B, (e) Station 18G, and (f) Station 18K in the plume in the eastern Manus basin.

hydrothermal plume peak level at all the stations are positive $\left(R^{2}>0.8, p<0.05\right)$ (Figure 4$)$, suggesting that $\mathrm{As}, \mathrm{Sb}$, and $\mathrm{Mn}$ are derived from the hydrothermal vent fluid source and indicating that As and $\mathrm{Sb}$ can also be used as a tracer, similarly to $\mathrm{Mn}$, to identify hydrothermal plumes (e.g., [57-60]). Further, the positive correlation between $\mathrm{As}$ and $\mathrm{Sb}\left(R^{2}>0.5\right.$, $p<0.05$ ) in the plume peak level (Figure 5) demonstrates that the dissolved As and $\mathrm{Sb}$ remaining in the plume share similar characteristics during their dilution by seawater (e.g., [29]). However, because of the ongoing rock-fluid interaction, magma degassing, and boiling and phase separation of hydrothermal fluid in hydrothermal systems, the As/Sb ratios in plume peak levels at Station 18B, 8G, and 18K are slightly different (Figure 5) despite the fact that As and Sb have similar geochemical behavior in the hydrothermal plumes.

The correlations between $\mathrm{Cl}$ and $\mathrm{Mn}, \mathrm{As}$, and $\mathrm{Sb}$ in the plume at Station 18B are positive $\left(R^{2}>0.7, p<0.05\right)$ (Figure 6), indicating that $\mathrm{Cl}$ in the plume at Station 18B has the same fluid source as Mn, As, and Sb. At Stations $18 \mathrm{~K}$ and $18 \mathrm{G}$, the correlations between $\mathrm{Cl}$ and $\mathrm{Mn}, \mathrm{As}$, and $\mathrm{Sb}$ in the lower plume peak level are negative $\left(R^{2}>0.6, p<0.05\right)$ (Figure 6), implying that the correlations between $\mathrm{Cl}$ and $\mathrm{Mn}$, $\mathrm{As}$, and $\mathrm{Sb}$ in the lower plume peak level result from a MnAs-Sb-enriched and Cl-depleted fluid.

5.3. As/Sb Ratios. The temperature varied widely $\left(3-3.8^{\circ} \mathrm{C}\right)$ at Stations $18 \mathrm{~B}, 18 \mathrm{G}$, and $18 \mathrm{~K}$, where the $\mathrm{As} / \mathrm{Sb}$ ratios in normal seawater decreased with increasing water temperature similarly to results reported in ocean surface water elsewhere [61], so, whether in the surface or in the deep water, the change of $\mathrm{As} / \mathrm{Sb}$ ratio with temperature shows the same trend (Figure 7). Many studies have shown that the concentration of $\mathrm{Sb}$ is almost constant from the surface to the bottom of the ocean (e.g., [61]); thus the change of As/Sb ratio with temperature in normal seawater is dominated by the effect of temperature on As, possibly indicating that the biological 


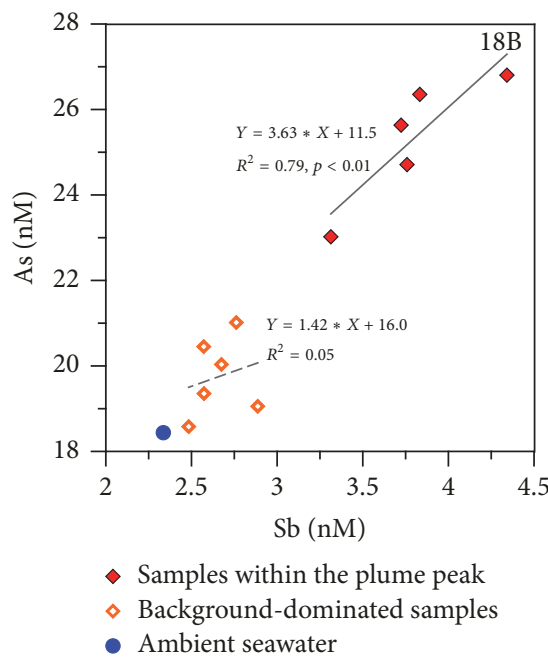

(a)

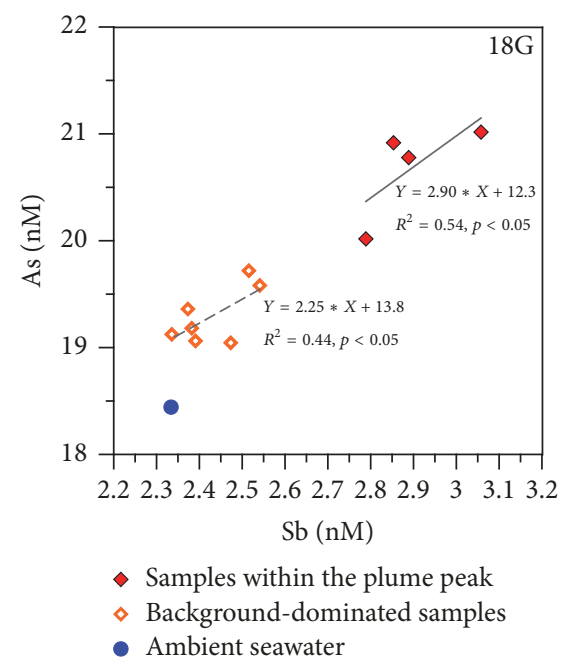

(b)

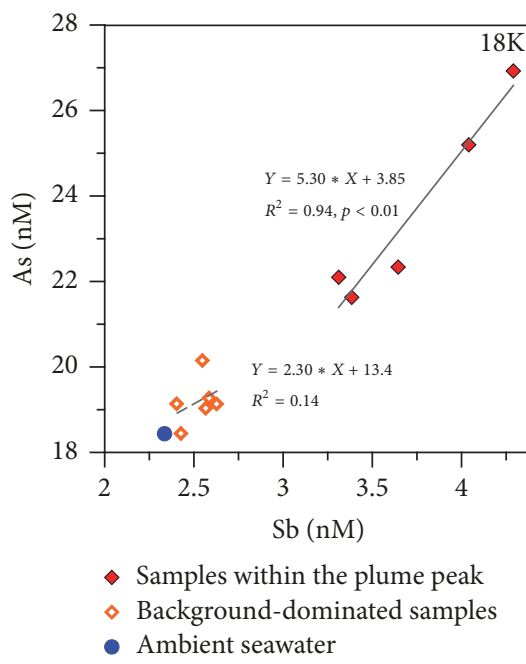

(c)

FIgURE 5: Correlations between As and Sb at (a) Station 18B, (b) Station 18G, and (c) Station 18K in the plume in the eastern Manus basin.

uptake of seawater As increased at higher temperature (e.g., [61]).

However, since the increase in As concentration in the anomalous layer, relative to background seawater levels, is lower than that of $\mathrm{Sb}, \mathrm{As} / \mathrm{Sb}$ ratios in the anomalous layer are lower than those in normal seawater at the same temperature (Figures 3 and 7), suggesting that the As/Sb ratio may be a tracer reflecting anomalous As and Sb levels in the hydrothermal plume water profiles. Further, the As/Sb ratio in the anomalous layer at Station $18 \mathrm{~K}$ is higher than that at Station $18 \mathrm{G}$ (Figure 7), possibly because the Sb content in the anomalous layer at Station $18 \mathrm{~K}$ is similar to that at Station $18 \mathrm{G}$, while the As content is higher than that at Station 18G (Figure 3).

5.4. A New Hydrothermal Vent May Exist Near Station $18 B$. Station $18 \mathrm{~B}\left(151^{\circ} 52^{\prime} \mathrm{W}, 3^{\circ} 41^{\prime} \mathrm{S}\right)$ is located at the northeast of the PACMANUS hydrothermal field and the DESMOS caldera, at about $35 \mathrm{~km}$ and $8 \mathrm{~km}$, respectively. Station $18 \mathrm{~B}$ is far away from the PACMANUS hydrothermal field, and the bottom current is from the southwest in this area [35], suggesting that the chemical anomaly of hydrothermal plume water column at Station 18B is not the result of the drift of the plume from the PACMANUS hydrothermal field. Further, the $\mathrm{Cl}$ and $\mathrm{Sb}$ contents in the DESMOS fluid ( $\mathrm{Cl} 490 \mathrm{mM}, \mathrm{Sb}<3.0 \mathrm{nM}$; [29]) are lower than those in the anomaly layer of hydrothermal plume water column at Station 18B, so the $\mathrm{Cl}$ and $\mathrm{Sb}$ anomaly of hydrothermal plume at Station 18B is also not the result of the drift of the plume from the DESMOS caldera, suggesting that there may be a new hydrothermal vent near Station $18 \mathrm{~B}$ and that the characteristics of vent fluid from the new vent field are similar to those of the PACMANUS fluid: enriched in $\mathrm{Mn}, \mathrm{As}, \mathrm{Sb}$, and $\mathrm{Cl}$ relative to ambient seawater.

\section{Conclusions}

In the SuSu Knolls hydrothermal field, the two plumes at Stations $18 \mathrm{G}$ and $18 \mathrm{~K}$ are both enriched in $\mathrm{As}, \mathrm{Sb}$, and $\mathrm{Mn}$ and depleted in $\mathrm{Cl}$, indicating that $\mathrm{As}-\mathrm{Sb}-\mathrm{Mn}$-enriched and $\mathrm{Cl}$ depleted vent fluid outputs to the hydrothermal plume water columns, which is most likely generated in the subseafloor by fluid-rock interaction, magma degassing, or boiling and phase separation of hydrothermal fluid. Further, the upper plume may emanate from near hydrothermal vent at Station $18 \mathrm{G}$ and the lower plume may have a hydrothermal source far from Station 18G.

The hydrothermal plume at Station $18 \mathrm{~B}$ is slightly enriched in $\mathrm{Cl}$ and significantly enriched in $\mathrm{As}, \mathrm{Sb}$, and $\mathrm{Mn}$, as a result of contribution of $\mathrm{Mn}$-As-Sb-Cl-enriched vent fluid discharges into the hydrothermal plume water profile, which have been generated by fluid-rock interaction, and indicating that a new hydrothermal vent may have appeared in that area. The profile of $\mathrm{As}, \mathrm{Sb}$, and $\mathrm{Mn}$ content with water depth is similar to that of the temperature anomaly. The distributions of As and $\mathrm{Sb}$ within the hydrothermal plume are not controlled by particle adsorption or biogeochemical cycles, suggesting that $\mathrm{As}$ and $\mathrm{Sb}$, like $\mathrm{Mn}$, can act as tracers of hydrothermal plumes in the seawater environment.

In the eastern Manus basin, the As/Sb ratios in the anomalous layer caused by hydrothermal activity do not follow the relationship between $\mathrm{As} / \mathrm{Sb}$ ratio and temperature for ambient seawater, suggesting that the $\mathrm{As} / \mathrm{Sb}$ ratio may be a tracer reflecting the effect of hydrothermal activity on As and $\mathrm{Sb}$ in the hydrothermal plume.

\section{Additional Points}

Research Highlights. (i) Temperature and $\mathrm{Mn}$, As, and $\mathrm{Sb}$ profiles in plume water columns are similar. (ii) There are positive correlations of $\mathrm{As}$ and $\mathrm{Sb}$ with $\mathrm{Mn}$ in the plumes. (iii) As and $\mathrm{Sb}$ can be used as tracers of hydrothermal plume. (iv) Plumes are enriched in $\mathrm{As}, \mathrm{Sb}, \mathrm{Mn}$, and $\mathrm{Cl}$ or depleted in $\mathrm{Cl}$. (v) As/Sb ratio may reflect hydrothermal effect on $\mathrm{As}$ and $\mathrm{Sb}$ in water column. 


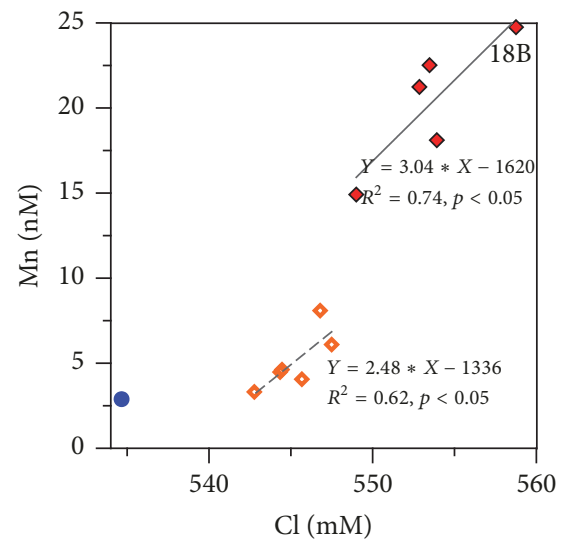

- Samples within the plume peak $\diamond$ Background-dominated samples

- Ambient seawater

(a)

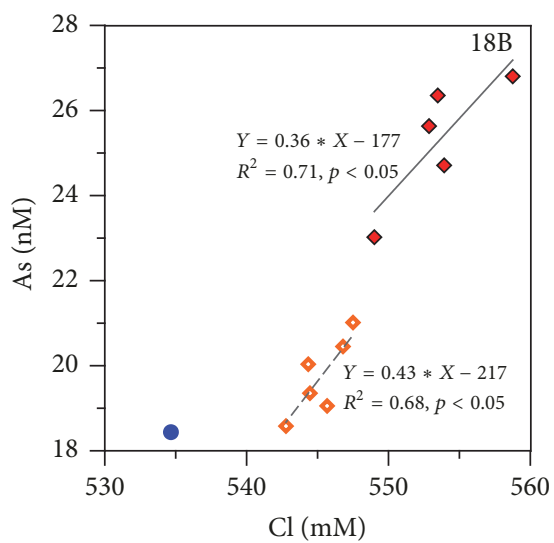

$\diamond$ Samples within the plume peak

$\diamond$ Background-dominated samples

- Ambient seawater

(d)

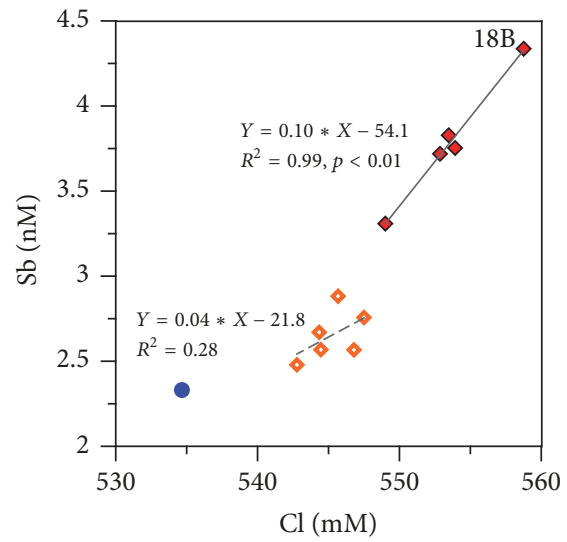

$\diamond$ Samples within the plume peak

$\diamond$ Background-dominated samples

- Ambient seawater

(g)

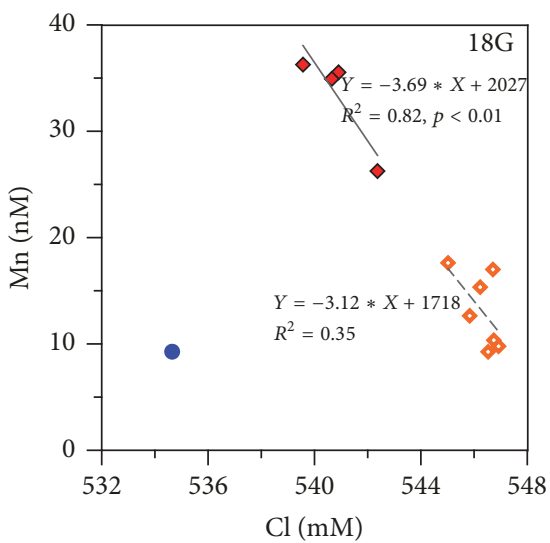

$\checkmark$ Samples within the plume peak

$\diamond$ Background-dominated samples

- Ambient seawater

(b)

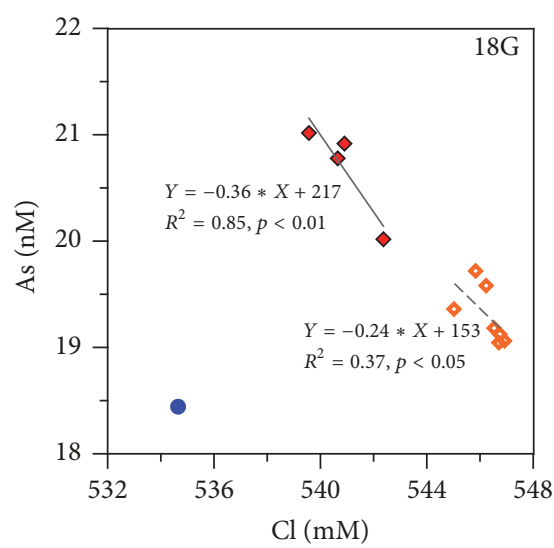

$\checkmark$ Samples within the plume peak

$\diamond$ Background-dominated samples

- Ambient seawater

(e)

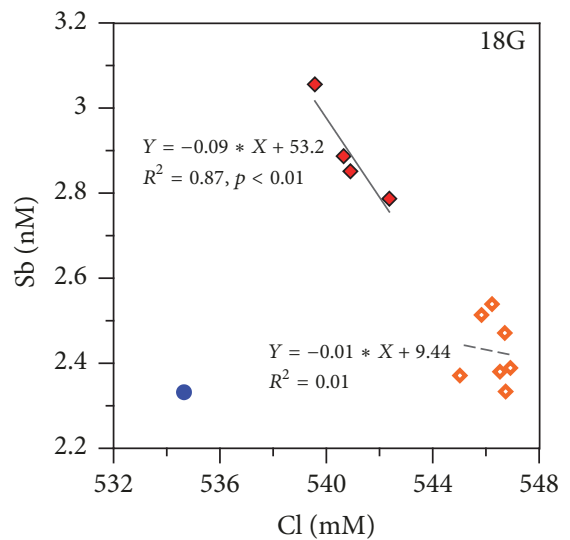

$\diamond$ Samples within the plume peak

$\diamond$ Background-dominated samples

- Ambient seawater

(h)

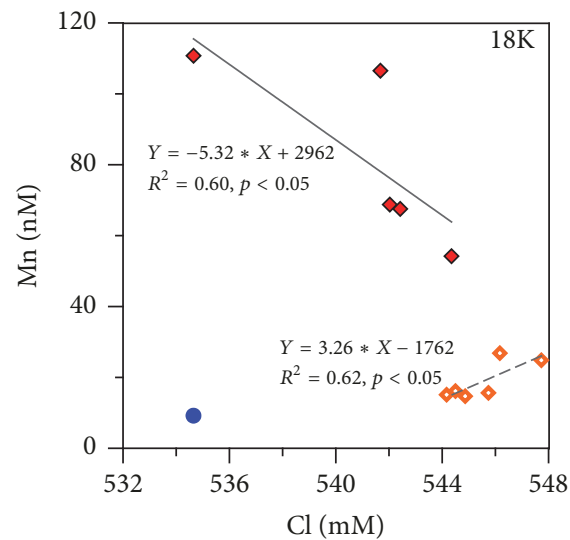

- Samples within the plume peak

$\diamond$ Background-dominated samples

- Ambient seawater

(c)

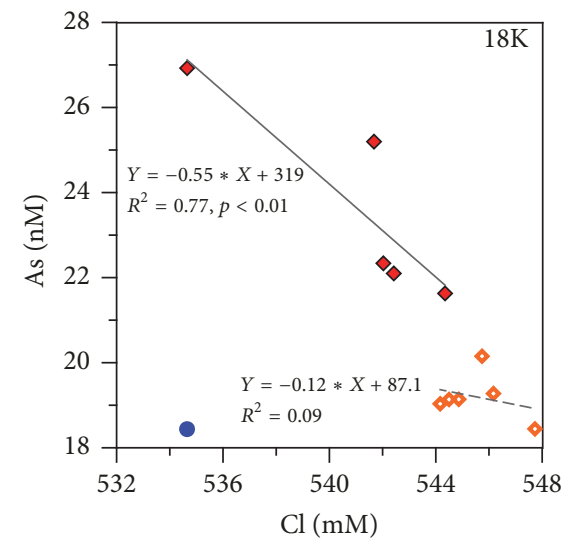

- Samples within the plume peak

$\diamond$ Background-dominated samples

- Ambient seawater

(f)

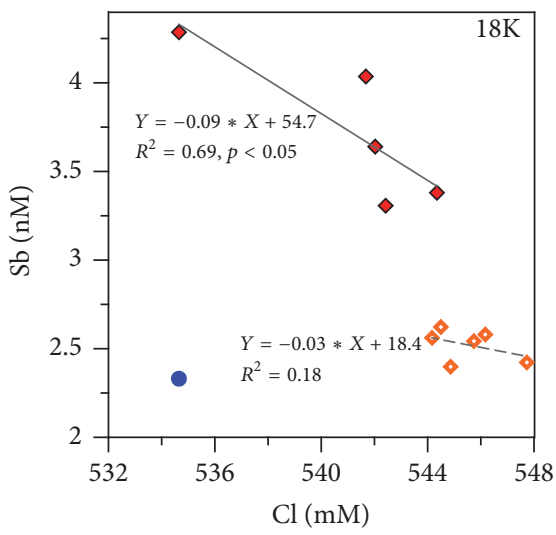

- Samples within the plume peak

$\diamond$ Background-dominated samples

- Ambient seawater

(i)

Figure 6: Correlations between Mn and Cl (a) at Station 18B, (b) at Station 18G, and (c) at Station 18K; correlations between As and Cl (d) at Station 18B, (e) at Station 18G, and (f) at Station 18K; and correlations between Sb and Cl (g) at Station 18B, (h) at Station 18G, and (i) at Station $18 \mathrm{~K}$ in the plume in the eastern Manus basin. 


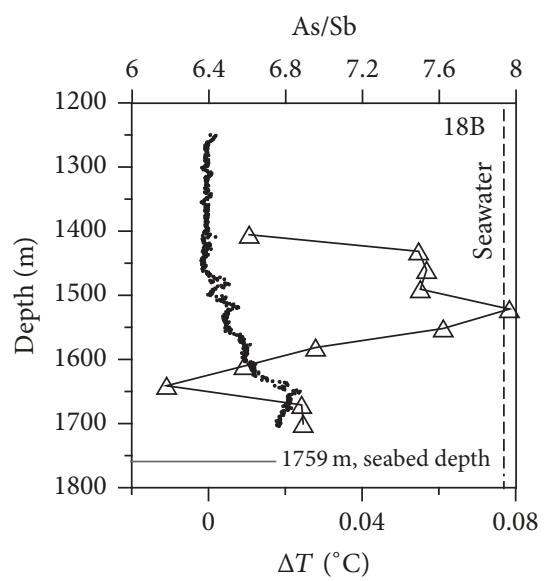

(a)

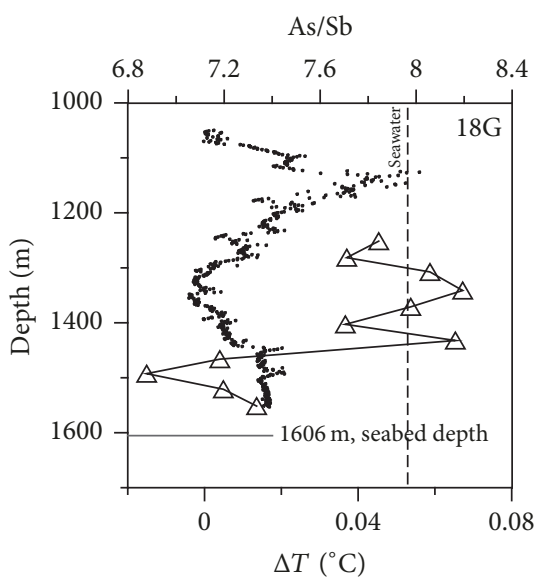

(b)

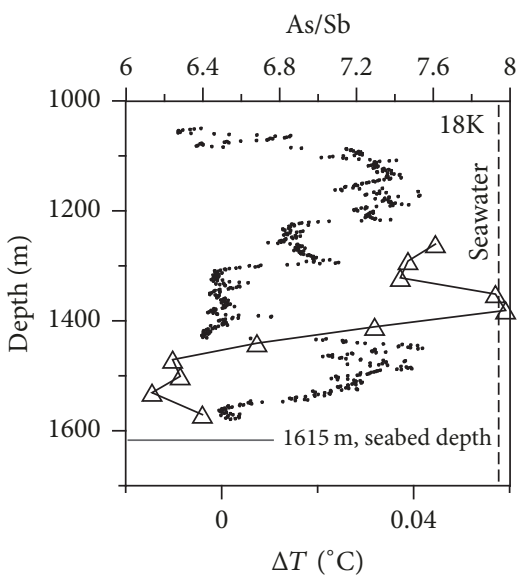

(c)

FIGURE 7: Vertical profiles of temperature anomaly and As/Sb ratio at Stations 18B (a), 18G (b), and 18K (c). “.” denotes the temperature anomaly, and " $\Delta$ " denotes the As/Sb ratio in the water column samples. The dashed line represents the ambient seawater As/Sb ratio (7.91). The seabed depths at Stations 18B, 18G, and 18K are $1759 \mathrm{~m}, 1606 \mathrm{~m}$, and $1615 \mathrm{~m}$, respectively.

\section{Conflicts of Interest}

The authors declare that they have no conflicts of interest.

\section{Acknowledgments}

The authors would like to thank the crew of the "KX08-973" cruise in the eastern Manus basin in 2008 for their support during sampling. They are most grateful for the detailed and constructive comments and suggestions provided by Dr. Ray Binns, which significantly improved the content of this paper. International Science Editing checked the English in the manuscript. This work was supported by the National Natural Science Foundation of China (Grant nos. 41325021, 414776044), the National Key Basic Research Program of China (Grant no. 2013CB429700), the Strategic Priority Research Program of the Chinese Academy of Sciences (Grant no. XDA11030302), the International Partnership Program of Chinese Academy of Sciences (Grant no. 133137KYSB20170003), the Special Fund for the Taishan Scholar Program of Shandong Province (Grant no. ts201511061), National Special Fund for the 13th Five-Year Plan of COMRA (Grant no. DY135-G2-1-02), the AoShan Talents Program Supported by the Qingdao National Laboratory for Marine Science and Technology (Grant no. 2015ASTP0S17), the Innovative Talent Promotion Program (Grant no. 2012RA2191), the Science and Technology Development Program of Shandong Province (Grant no. 2013GRC31502), the Scientific and Technological Innovation Project financially supported by the Qingdao National Laboratory for Marine Science and Technology (Grant nos. 2015ASKJ03, 2016ASKJ13), and the National High-Level Talent Special Support Program.

\section{References}

[1] J. L. Charlou, H. Bougault, P. Appriou, P. Jean-Baptiste, J. Etoubleau, and A. Birolleau, "Water column anomalies associated with hydrothermal activity between $11^{\circ} 40^{\prime}$ and $13^{\circ} \mathrm{N}$ on the East Pacific rise: discrepancies between tracers," Deep-Sea Research Part I: Oceanographic Research Papers, vol. 38, no. 5, pp. 569596, 1991.

[2] E. T. Baker and J. E. Lupton, "Changes in submarine hydrothermal $3 \mathrm{He} /$ heat ratios as an indicator of magmatic/tectonic activity," Nature, vol. 346, no. 6284, pp. 556-558, 1990.

[3] J. P. Cowen, M. A. Bertram, S. G. Wakeham et al., "Ascending and descending particle flux from hydrothermal plumes at Endeavour Segment, Juan de Fuca Ridge," Deep-Sea Research Part I: Oceanographic Research Papers, vol. 48, no. 4, pp. 10931120, 2001.

[4] D. S. Kelley, M. D. Lilley, J. E. Lupton, and E. J. Olson, "Enriched $\mathrm{H}_{2}, \mathrm{CH}_{4},{ }^{3} \mathrm{He}$ concentrations in hydrothermal plumes associated with the 1996 Gorda Ridge eruptive event," Deep-Sea Research Part II: Topical Studies in Oceanography, vol. 45, no. 12, pp. 2665-2682, 1998.

[5] P. Lam, J. P. Cowen, and R. D. Jones, "Autotrophic ammonia oxidation in a deep-sea hydrothermal plume," FEMS Microbiology Ecology, vol. 47, no. 2, pp. 191-206, 2004.

[6] K. Okamura, H. Kimoto, K. Saeki et al., "Development of a deepsea in situ Mn analyzer and its application for hydrothermal plume observation," Marine Chemistry, vol. 76, no. 1-2, pp. 1726, 2001.

[7] X. Wang, Z. Zeng, C. Liu et al., "Geochemical anomalies of hydrothermal plume at EPR $13^{\circ} \mathrm{N}$," Science China Earth Sciences, vol. 50, no. 9, pp. 1433-1440, 2007.

[8] C. S. Chin, G. P. Klinkhammer, and C. Wilson, "Detection of hydrothermal plumes on the northern Mid-Atlantic Ridge: Results from optical measurements," Earth and Planetary Science Letters, vol. 162, no. 1-4, pp. 1-13, 1998.

[9] H. N. Edmonds, P. J. Michael, E. T. Baker et al., "Discovery of abundant hydrothermal venting on the ultraslow-spreading Gakkel ridge in the Arctic Ocean," Nature, vol. 421, no. 6920, pp. 252-256, 2003.

[10] T. Gamo, H. Chiba, T. Yamanaka et al., "Chemical characteristics of newly discovered black smoker fluids and associated hydrothermal plumes at the Rodriguez Triple Junction, Central 
Indian Ridge," Earth and Planetary Science Letters, vol. 193, no. 3-4, pp. 371-379, 2001.

[11] L. A. McDonald, R. A. Binns, A. M. Huff, and S. D. Scott, "Locating active seafloor hydrothermal deposits using particulate plumes: the Susu Knoll example," in Abstracts from the 14th Australian Geological Convention, Townsville, Australia, 1998.

[12] T. Gamo, H. Sakai, J. Ishibashi et al., "Hydrothermal plumes in the eastern Manus Basin, Bismarck Sea: $\mathrm{CH}_{4}, \mathrm{Mn}, \mathrm{Al}$ and $\mathrm{pH}$ anomalies," Deep-Sea Research Part I: Oceanographic Research Papers, vol. 40, no. 11-12, pp. 2335-2349, 1993.

[13] R. S. Keir, J. Sültenfuß, M. Rhein, G. Petrick, and J. Greinert, "Separation of ${ }^{3} \mathrm{He}$ and $\mathrm{CH}_{4}$ signals on the Mid-Atlantic Ridge at $5^{\circ} \mathrm{N}$ and $51^{\circ} \mathrm{N}$," Geochimica et Cosmochimica Acta, vol. 70, no. 23, pp. 5766-5778, 2006.

[14] A. P. Lisitzin, V. N. Lukashin, V. V. Gordeev, T. F. McConachy, S. D. Scott, and V. P. Shevchenko, "Hydrological and geochemical anomalies associated with hydrothermal activity in SW Pacific marginal and back-arc basins," Marine Geology, vol. 142, no. 1-4, pp. 7-45, 1997.

[15] J. E. Lupton, E. T. Baker, and G. J. Massoth, "Helium, heat, and the generation of hydrothermal event plumes at mid-ocean ridges," Earth and Planetary Science Letters, vol. 171, no. 3, pp. 343-350, 1999.

[16] G. J. Massoth, E. T. Baker, R. A. Feely et al., "Manganese and iron in hydrothermal plumes resulting from the 1996 Gorda Ridge event," Deep-Sea Research Part II: Topical Studies in Oceanography, vol. 45, no. 12, pp. 2683-2712, 1998.

[17] M. Paulfield and R. Sherrell, "Dissolved and particulate Fe in a hydrothermal plume at $9^{\circ} 45^{\prime} \mathrm{N}$, East Pacific Rise: Slow Fe (II) oxidation kinetics in Pacific plumes," Geochimica et Cosmochimica Acta, vol. 64, no. 4, pp. 619-628, 2000.

[18] P. J. Statham, C. R. German, and D. P. Connelly, "Iron (II) distribution and oxidation kinetics in hydrothermal plumes at the Kairei and Edmond vent sites, Indian Ocean," Earth and Planetary Science Letters, vol. 236, no. 3-4, pp. 588-896, 2005.

[19] H. Zhou, Z. Wu, X. Peng, L. Jiang, and S. Tang, "Detection of methane plumes in the water column of Logatchev hydrothermal vent field, Mid-Atlantic Ridge," Chinese Science Bulletin, vol. 52, no. 15, pp. 2140-2146, 2007.

[20] R. A. Binns, J. M. Parr, S. D. Scott, J. B. Gemmell, and P. M. Herzig, "PACMANUS: an active seafloor hydrothermal field on siliceous volcanic rocks in the eastern Manus Basin, Papua New Guinea," in Proceedings of the 1995 PACRIM Congress, J. L. Mauk and J. D. St. George, Eds., AusIMM Bull., pp. 49-54, 1995.

[21] E. Hrischeva, S. D. Scott, and R. Weston, "Metalliferous sediments associated with presently forming volcanogenic massive sulfides: The SuSu Knolls hydrothermal field, eastern Manus basin, Papua New Guinea," Economic Geology, vol. 102, no. 1, pp. 55-73, 2007.

[22] R. A. Binns, S. D. Scott, J. B. Gemmell, K. A. W. C. Crook, and The Shipboard Party, "The SuSu Knolls hydrothermal field, eastern Manus Basin," PNG. Eos Trans. AGU 78 (46), 772, 1997.

[23] R. E. Price, I. Savov, B. Planer-Friedrich, S. I. Bühring, J. Amend, and T. Pichler, "Processes influencing extreme as enrichment in shallow-sea hydrothermal fluids of milos island, greece," Chemical Geology, vol. 348, pp. 15-26, 2013.

[24] M. J. Ruiz-Chancho, T. Pichler, and R. E. Price, "Arsenic occurrence and speciation in Cyclope neritea, a gastropod inhabiting the arsenic-rich marine shallow-water hydrothermal system off Milos Island, Greece," Chemical Geology, vol. 348, pp. 56-64, 2013.
[25] R. E. Villanueva-Estrada, R. M. Prol-Ledesma, A. A. RodríguezDíaz, C. Canet, and M. A. Armienta, "Arsenic in hot springs of Bahía Concepción, Baja California Peninsula, México," Chemical Geology, vol. 348, pp. 27-36, 2013.

[26] C. Breuer and T. Pichler, "Arsenic in marine hydrothermal fluids," Chemical Geology, vol. 348, pp. 2-14, 2013.

[27] G. S. Pokrovski, I. V. Zakirov, J. Roux et al., "Experimental study of arsenic speciation in vapor phase to $500^{\circ} \mathrm{C}$ : Implications for As transport and fractionation in low-density crustal fluids and volcanic gases," Geochimica et Cosmochimica Acta, vol. 66, no. 19, pp. 3453-3480, 2002.

[28] G. S. Pokrovski, A. Y. Borisova, J. Roux et al., "Antimony speciation in saline hydrothermal fluids: A combined X-ray absorption fine structure spectroscopy and solubility study," Geochimica et Cosmochimica Acta, vol. 70, no. 16, pp. 4196-4214, 2006.

[29] É. Douville, J. Charlou, J. Donval, D. Hureau, and P. Appriou, "Le comportement de l'arsenic (As) et de l'antimoine (Sb) dans les fluides provenant de différents systèmes hydrothermaux océaniques," Comptes Rendus de l'Académie des Sciences - Series IIA - Earth and Planetary Science, vol. 328, no. 2, pp. 97-104, 1999.

[30] K. L. Von Damm, "Temporal and compositional diversity in seafloor hydrothermal fluids," Reviews of Geophysics, Supplement, U.S. National Report to International Union of Geodesy and Geophysics 1991-1994, pp. 1297-1305, 1995.

[31] D. A. Butterfield, I. R. Jonasson, G. J. Massoth et al., "Seafloor eruptions and evolution of hydrothermal fluid chemistry," Philosophical Transactions of the Royal Society A: Mathematical, Physical \& Engineering Sciences, vol. 355, no. 1723, pp. 369-386, 1997.

[32] M. Filella, N. Belzile, and Y. Chen, "Antimony in the environment: a review focused on natural waters: I. Occurence," EarthScience Reviews, vol. 57, no. 1-2, pp. 125-176, 2002.

[33] S. Roberts, W. Bach, R. A. Binns et al., "Contrasting evolution of hydrothermal fluids in the PACMANUS system, Manus Basin: The Sr and S isotope evidence," Geology, vol. 31, no. 9, pp. 805808, 2003.

[34] M. D. Hannington, C. E. J. de Ronde, and S. Petersen, "Sea-floor tectonics and submarine hydrothermal systems," Economic Geology 100th Anniversary Volume, pp. 111-141, 2005.

[35] R. A. Binns and S. D. Scott, "Scientific communications: Actively forming polymetallic sulfide deposits associated with felsic volcanic rocks in the eastern manus back-arc basin, Papua New Guinea," Economic Geology, vol. 88, no. 8, pp. 2226-2236, 1993.

[36] J. M. Sinton, L. L. Ford, B. Chappell, and M. T. McCulloch, "Magma genesis and mantle heterogeneity in the Manus backArc Basin, Papua New Guinea," Journal of Petrology, vol. 44, no. 1, pp. 159-195, 2003.

[37] W. Bach, J. S. Seewald, M. A. Tivey et al., "Hydrothermal systems in the eastern manus basin: effects of phase separation and fluid mixing," Goldschmidt Conference Abstracts, A48, 2007.

[38] T. Gamo, K. Okamura, J.-L. Charlou et al., "Acidic sulfate-rich hydrothermal fluids from the Manus back-arc basin, Papua New Guinea," Geology, vol. 25, no. 2, pp. 139-142, 1997.

[39] J. Ishibashi, T. Yamanaka, K. Okamura et al., "Geochemical studies of magmatic hydrothermal activity in the DESMOS cauldron, Manus back arc basin," JAMSTEC Journal Deep Sea Research, vol. 13, pp. 243-248, 1997. 
[40] I. Lipton, "Mineral resource estimate. Solwara project, Bismarck sea, Papua New Guinea," Technical report compiled under NI43-101, 2011.

[41] F. Barriga, R. Binns, J. Baldauf, and D. Miller, Anatomy of an active, felsic-hosted hydrothermal system, eastern Manus basin. College Station, TX, Leg 193 Scientific Prospectus, Ocean Drilling Program, 2000.

[42] R. A. Binns, F. J. A. S. Barriga, D. J. Miller, and The Shipboard Party, "Anatomy of an active felsic-hosted hydrothermal system, eastern Manus basin, Sites 1188-1191, November 2000-January 2001," Proceedings of the Ocean Drilling Program Initial Reports, vol. 193, p. 84, 2002.

[43] R. A. Binns, J. M. Parr, and C. J. Yeats, "The PACMANUS seafloor sulfide field, Eastern Manus Basin, Papua New Guinea," in PACRIM Congress 2008, Gold Coast, Queensland, The Pacific Rim: Mineral Endowment, Discoveries, \& Exploration Frontiers, pp. 73-78, The Australasian Institute of Mining and Metallurgy, Carlton, Victoria, Australia, 2008.

[44] Z. Zeng, H. Ouyang, X. Yin, S. Chen, X. Wang, and L. Wu, "Formation of Fe-Si-Mn oxyhydroxides at the PACMANUS hydrothermal field, Eastern Manus Basin: Mineralogical and geochemical evidence," Journal of Asian Earth Sciences, vol. 60, pp. 130-146, 2012.

[45] J. Hashimoto and S. Ohta, "Hydrothermal vent fields and ventassociated biological communities in the manus basin," in SOPAC Cruise Report 148, 1999.

[46] E. P. Reeves, J. S. Seewald, P. Saccocia et al., "Geochemistry of hydrothermal fluids from the PACMANUS, Northeast Pual and Vienna Woods hydrothermal fields, Manus Basin, Papua New Guinea," Geochimica et Cosmochimica Acta, vol. 75, no. 4, pp. 1088-1123, 2011.

[47] R. A. Binns, "Eastern Manus Basin, Papua New Guinea: guides for volcanogenic massive sulphide exploration from a modern seafloor analogue," in Copper-zinc massive sulphide deposits in Western Australia, CSIRO Explores 2, T. F. McConachy and B. I. A. McInnes, Eds., pp. 55-76, 2004.

[48] J. C. Waters and R. A. Binns, "Contrasting styles of felsic submarine volcanism, eastern manus basin, Papua New Guinea," in Abstracts from the 14th Australian Geological Convention, Townsville, Australia, 1998.

[49] S.-H. Park, S.-M. Lee, G. D. Kamenov, S.-T. Kwon, and K.-Y. Lee, "Tracing the origin of subduction components beneath the South East rift in the Manus Basin, Papua New Guinea," Chemical Geology, vol. 269, no. 3-4, pp. 339-349, 2010.

[50] K. Gena, T. Mizuta, D. Ishiyama, and T. Urabe, "Acid-sulphate type alteration and mineralization in the Desmos caldera, Manus back-arc basin, Papua New Guinea," Resource Geology, vol. 51, no. 1, pp. 31-44, 2001.

[51] T. J. McDougall, "Bulk properties of 'hot smoker' plumes," Earth and Planetary Science Letters, vol. 99, no. 1-2, pp. 185-194, 1990.

[52] K. G. Speer and P. A. Rona, "A model of an Atlantic and Pacific hydrothermal plume," Journal of Geophysical Research: Atmospheres, vol. 94, no. C5, pp. 6213-6220, 1989.

[53] J. Thal, M. Tivey, D. Yoerger, N. Jöns, and W. Bach, "Geologic setting of PACManus hydrothermal area - High resolution mapping and in situ observations," Marine Geology, vol. 355, pp. 98114, 2014.

[54] W. Bach, S. Roberts, D. A. Vanko et al., "Controls of fluid chemistry and complexation on rare-earth element contents of anhydrite from the Pacmanus subseafloor hydrothermal system, Manus Basin, Papua New Guinea," Mineralium Deposita, vol. 38, no. 8, pp. 916-935, 2003.
[55] K. L. Von Damm, A. M. Bray, L. G. Buttermore, and S. E. Oosting, "The geochemical controls on vent fluids from the Lucky Strike vent field, Mid-Atlantic Ridge," Earth and Planetary Science Letters, vol. 160, no. 3-4, pp. 521-536, 1998.

[56] S. D. Scott, K. Yang, M. Constantin, and R. Moss, "Hydrothermal Processes and Mineralization at Mid-ocean Ridges and Back Arcs: the Explorer and Manus Examples," in Abstracts from the American Geophysical Union Fall conference, San Fransisco, EOS Transactions AGU, 78, 46, 1997.

[57] R. A. Feely, J. H. Trefry, G. J. Massoth, and S. Metz, "A comparison of the scavenging of phosphorus and arsenic from seawater by hydrothermal iron oxyhydroxides in the Atlantic and Pacific Oceans," Deep-Sea Research Part I: Oceanographic Research Papers, vol. 38, no. 6, pp. 617-623, 1991.

[58] C. R. German, A. C. Campbell, and J. M. Edmond, "Hydrothermal scavenging at the Mid-Atlantic Ridge: Modification of trace element dissolved fluxes," Earth and Planetary Science Letters, vol. 107, no. 1, pp. 101-114, 1991.

[59] J. E. Lupton, J. R. Delaney, H. P. Johnson, and M. K. Tivey, "Entrainment and vertical transport of deep-ocean water by buoyant hydrothermal plumes," Nature, vol. 316, no. 6029, pp. 621-623, 1985.

[60] M. D. Rudnicki and H. Elderfield, "A chemical model of the buoyant and neutrally buoyant plume above the TAG vent field, $26^{\circ} \mathrm{N}$, Mid-Atlantic Ridge," Geochimica et Cosmochimica Acta, vol. 57, no. 13, pp. 2939-2957, 1992.

[61] S. Tanaka and S. J. Santosa, "The concentration distribution and chemical form of arsenic compounds in sea water," in Biogeochemical Processes and Ocean Flux in the Western Pacific, $\mathrm{H}$. Sakai and Y. Nozaki, Eds., pp. 159-170, Terra Scientific Publishing Company (TERRAPUB), Tokyo, Japan, 1995. 

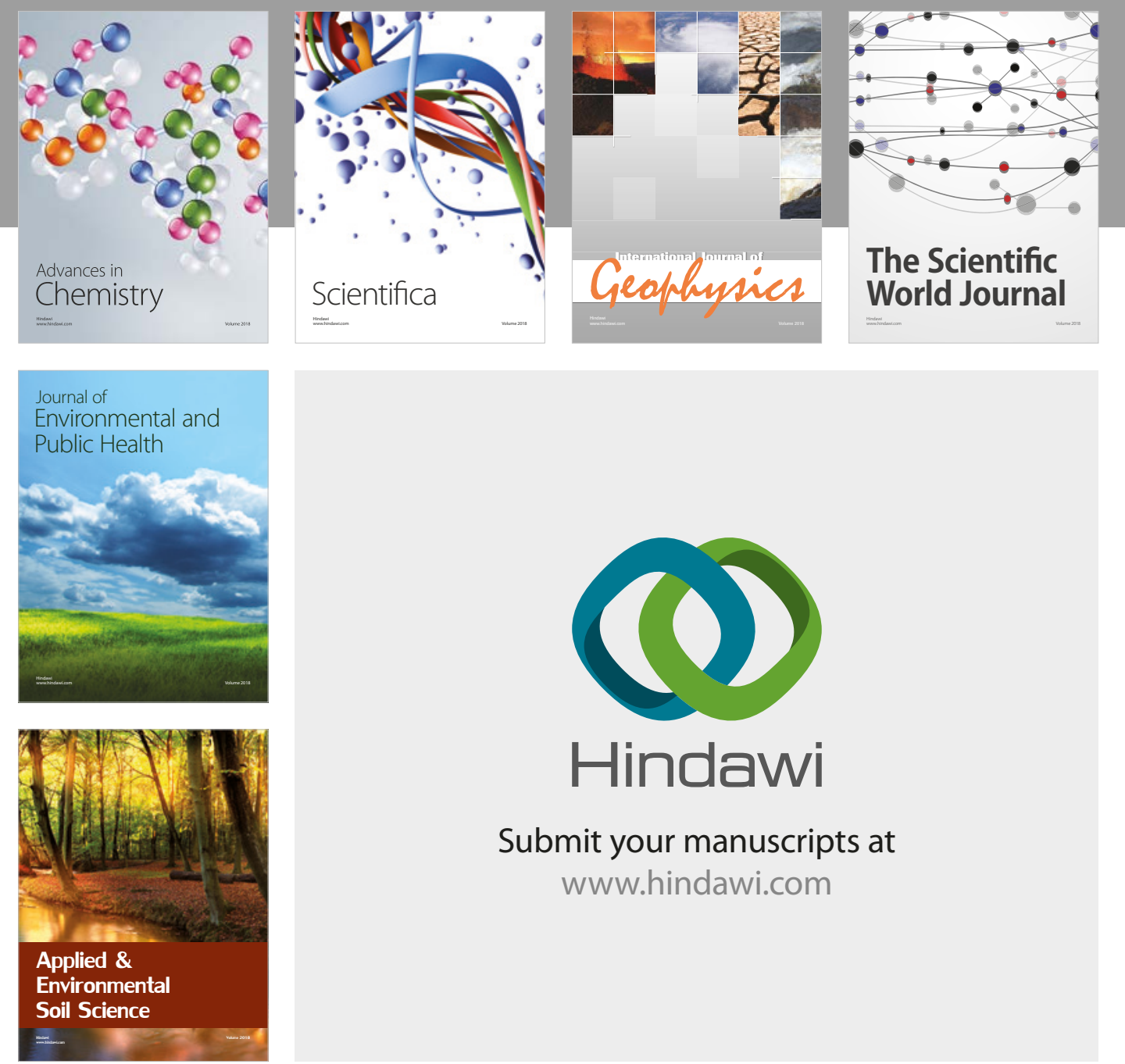

The Scientific

\section{World Journal}
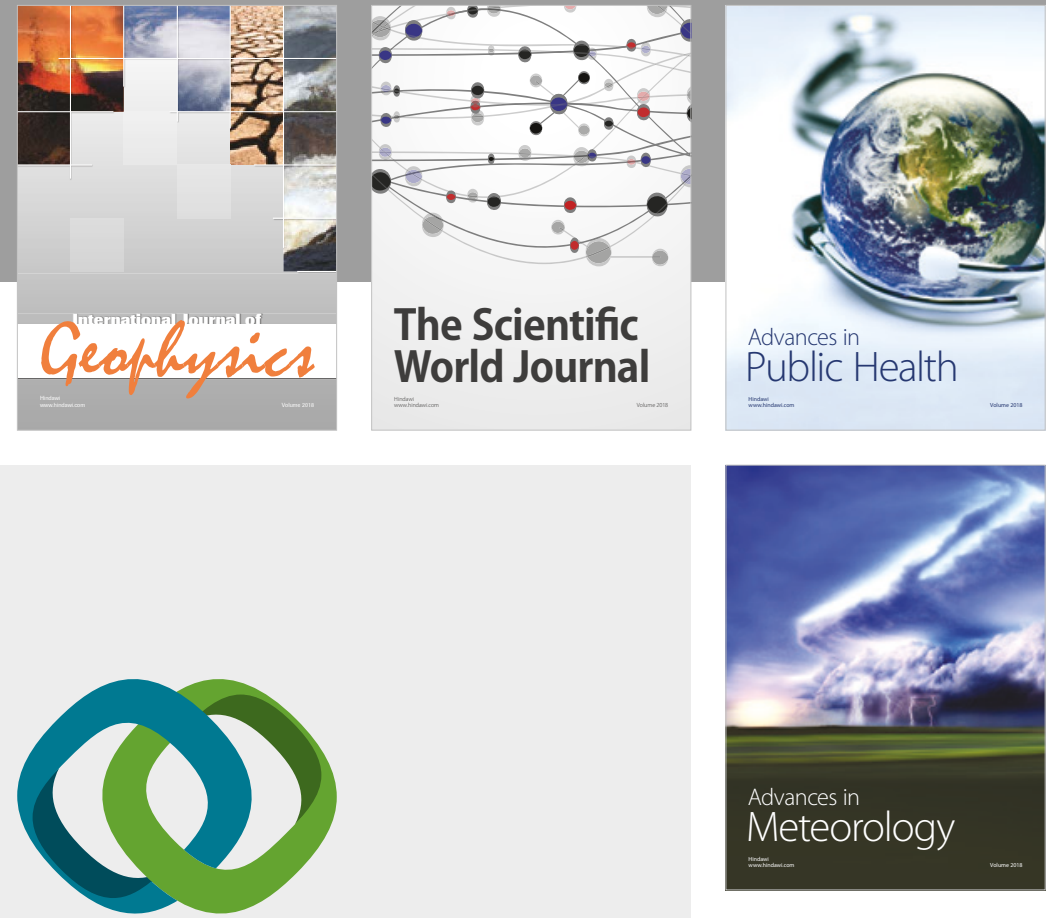

Advan

Public Health

\section{Hindawi}

Submit your manuscripts at

www.hindawi.com
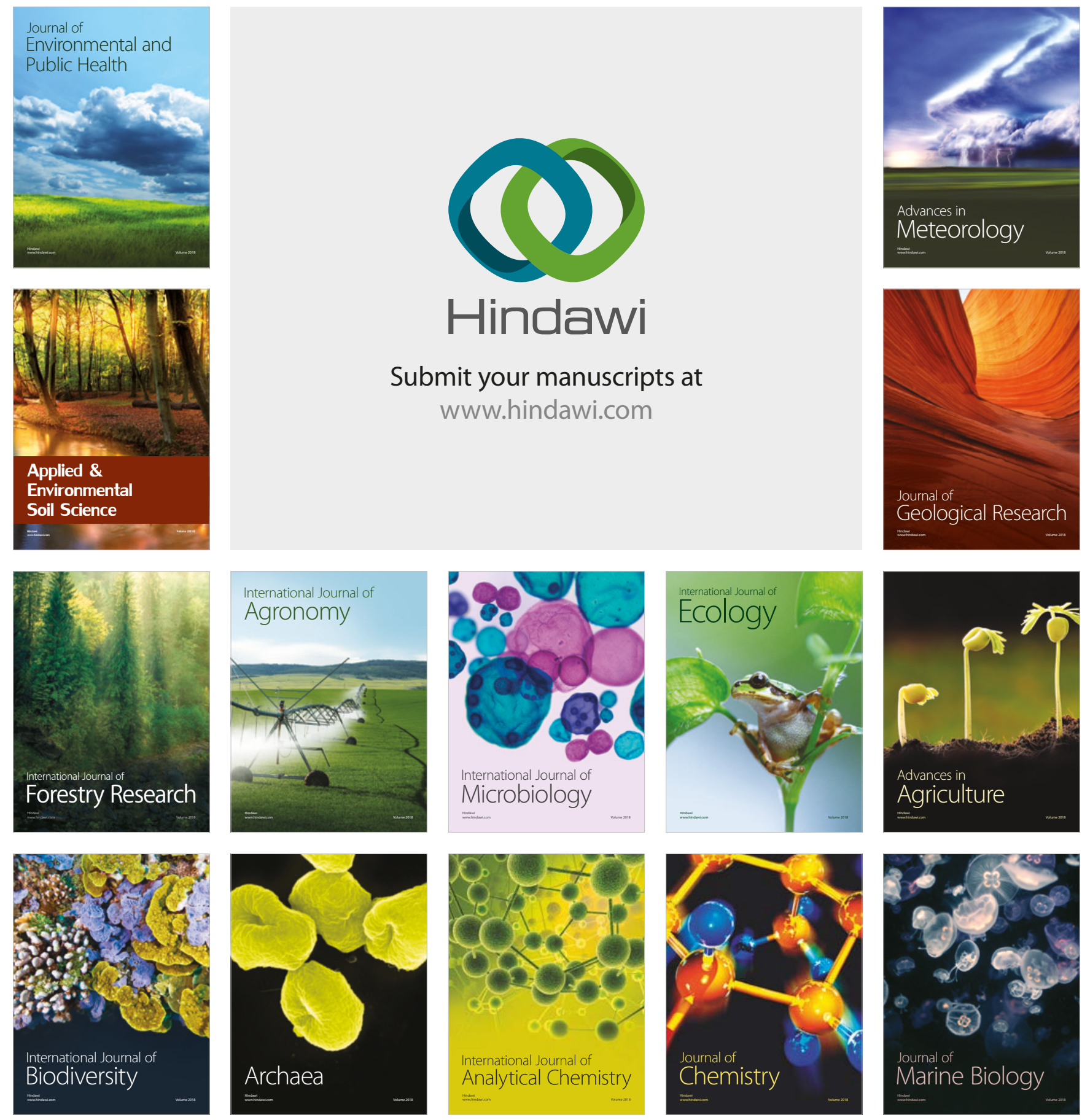